Boston University School of Law

Scholarly Commons at Boston University School of Law

Faculty Scholarship

Fall 2021

\title{
Do Lenders Still Monitor? Leveraged Lending and the Search for Covenants
}

Frederick Tung

Boston Univeristy School of Law

Follow this and additional works at: https://scholarship.law.bu.edu/faculty_scholarship

Part of the Banking and Finance Law Commons

\section{Recommended Citation}

Frederick Tung, Do Lenders Still Monitor? Leveraged Lending and the Search for Covenants, in 47 Journal of Corporation Law 153 (2021).

Available at: https://scholarship.law.bu.edu/faculty_scholarship/1169

This Article is brought to you for free and open access by Scholarly Commons at Boston University School of Law. It has been accepted for inclusion in Faculty Scholarship by an authorized administrator of Scholarly Commons at Boston University School of Law. For more information, please contact lawlessa@bu.edu. 


\title{
Do LENDERS STILL MONITOR? \\ LEVERAGEd LENDING AND THE SEARCH FOR COVENANTS
}

\author{
FREDERICK TUNG* \\ JULY 7, 2021
}

\begin{abstract}
It was once conventional wisdom that lenders routinely influenced corporate managers' decision making. Covenants constrained borrower risk taking and compelled specific affirmative obligations to protect lenders. Recent policy discussion, however, laments loan markets' turn to various forms of high-risk lending. So-called leveraged loans-relatively risky, below-investment-grade loans - more than doubled in outstanding dollar terms, growing from about $\$ 550$ billion in 2010 to $\$ 1.2$ trillion by 2019 . These risky loans have taken up a larger and larger share of the loan markets over time. More leveraged loans are also "covenant-lite," issued without traditional financial maintenance covenants. And regulators worry about "add-backs"- borrowers' growing practice of making upward adjustments to projected earnings that tend to weaken leverage constraints.

Moreover, bank regulatory changes have incentivized "originate-todistribute" loan syndications that enable non-bank lenders to hold and trade leveraged loans too risky for banks to keep. Syndicated lending now involves greater and greater participation by nonbank or "institutional" lenders like hedge funds, CLOs (collateralized loan obligations), and mutual funds. Commentators worry about the new species of risky loans, with their dearth of traditional covenants and the fewer instances of lender intervention, which may portend instability in debt markets. At the same time, weakened covenant protections may lead to weakened corporate governance.

In this Article, I respond to these fears, arguing that they may be overblown. The increasing share of leveraged and covenant-lite loans may not necessarily evidence undisciplined debt issuance. Many seemingly troublesome loans are issued as subparts of deals that include loans with traditional covenants and cross-default provisions, which effectively constrain borrower behavior. Though add-backs may increase firm leverage, they may also improve the informativeness of earnings-based financial covenants. In addition, while the incidence of loan covenant violations has dropped dramatically across U.S. public firms, recent research suggests that covenants have become more efficient. In effect, covenants are doing more with less. Financial covenants have generally become less restrictive and more discriminating in differentiating distress from non-distress situations.
\end{abstract}

\footnotetext{
* Howard Zhang Faculty Research Scholar, Associate Dean for Equity, Justice and Engagement, and Professor of Law, Boston University School of Law (fredtung@bu.edu). Many thanks to Gary Lawson, Naomi Mann, David Seipp, David Walker, and Kat Zeiler for helpful comments and conversation, as well as workshop participants at the Boston University School of Law.
} 


\section{Do LENDERS STILL MONITOR? \\ LEVERAGED LENDING AND THE SEARCH FOR COVENANTS}

FREDERICK TUNG

JULY 7, 2021

INTRODUCTION

I. TRADITIONAL BANK LENDING: COVENANTS AND MONITORING 6

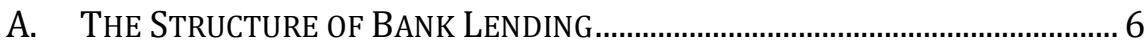

B. TRADITIONAL COVENANT STRUCTURE ........................................................... 8

1. Covenant Setting to Control Agency Costs.......................................... 8

2. Covenant Violations ............................................................................... 9

3. Lender Governance.............................................................................. 11

II. THE NEW LOAN MARKETS..........................................................14

A. TRADITIONAL SYNDICATED BANK LENDING …………………………….......14

B. DEMAND FOR LEVERAGED LOANS ..............................................................17

1. Banking Deregulation and Financial Firms' Consolidation..........17

2. Junk Bonds and Leveraged Buyouts.....................................................20

3. Modernizing Bank Capital...............................................................21

4. Securitization: Collateralized Loan Obligations................................23

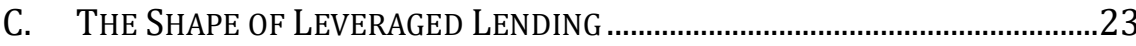

D. FEAR OF FLYING: REGULATORS' VIEW ..................................................25

III. THE NEW LENDER GOVERNANCE .....................................................28

A. SPLIT CONTROL …………………………………………………………….....29

B. EARNINGS ADD-BACKS AND INFORMATIVENESS............................................32

C. THE TURN TOWARD EFFICIENT CovEnANTS....................................................35

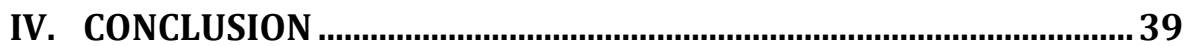




\title{
DO LENDERS STILL MONITOR?: LEVERAGED LENDING AND THE SEARCH FOR COVENANTS
}

\author{
FREDERICK TUNG
}

JULY 7, 2021

\section{INTRODUCTION}

Forty-odd years ago, financial economists began to teach us about the important interactions between capital structure and corporate governance, explaining why the structure of firms' debt contracts matters for corporate governance. ${ }^{1}$ The finance literature continues to document the ways that various features of lending contracts constrain managers' behavior. Lenders routinely influence corporate decision making, even outside the distress context. The pervasiveness of lender influence in public companies suggests that lender constraints-loan covenants - may often substitute for or complement conventional corporate governance. ${ }^{2}$ Banks may be better realtime monitors of corporate decision making than corporate boards, which do not enjoy the regular stream of information that banks receive. Banks enjoy enormous advantages over other outsiders - even the borrower firm's outside directors - in terms of access to the firm's managers and private information. ${ }^{3}$ The beneficent effects of bank monitoring on firm value have been well

\footnotetext{
${ }^{1}$ E.g., Clifford W. Smith, Jr. \& Jerold B. Warner, On Fnancial Contracting, 7 J. Fin. ECON. 117 (1979).

${ }^{2}$ Conventional internal and external corporate governance mechanisms - independent boards and markets for corporate control, for example-may be less critical in the presence of bank lending, since bank monitoring can substitute for these governance mechanisms. Steven S. Byers, L. Paige Fields \& Donald R. Fraser, Are Corporate Governance and Bank Monitoring Substitutes: Evidence from the Perceived Value of Bank Loans, 14 J. CORP. FIN. 475, 476 (2008) (finding that loan announcements are more likely to generate positive wealth effects for firms with weak internal and external corporate governance, which suggests that bank monitoring may substitute for weak governance); Ioannis Spyridopoulos, Tough Love: The Effect of Debt Contract Design on Firms' Performance, 9 REV. CORP. FIN. STUD. 44, 47 (2020) (finding that even absent any covenant violation, stricter loan covenants improve performance of firms with managerial agency conflicts - those (a) without a large monitoring blockholder; (b) facing softer product market competition; or (c) with entrenched management). See also Sungyoon Ahn \& Wooseok Choi, The Role of Bank Monitoring in Corporate Governance: Evidence from Borrowers' Earnings Management Behavior, 33 J. BANK. \& FIN. 425 (2009) (finding that borrower firms' earnings management behavior decreases as the strength of bank monitoring increases).

${ }^{3}$ Frederick Tung, Leverage in the Boardroom: The Unsung Influence of Private Lenders in Corporate Governance, 57 UCLA LAW. REV. 115, 125 (2009).
} 


\section{Do Lenders Still Monitor? \\ Leveraged Lending and the Search for Covenants}

documented over the past few decades, ${ }^{4}$ and the finance literature continues to expand the mapping of lender governance. ${ }^{5}$

Various observers of the lending markets, however, including regulators and rating agencies, foresee potential trouble ahead. Covenants are disappearing; lender interventions are becoming more rare. ${ }^{6}$ Without loan covenants, there is no lender governance or monitoring. The leveraged loan market triggers special concern. Leveraged loans are relatively risky, belowinvestment-grade loans. ${ }^{7}$ Over the last decade, this market has exploded, more than doubling in size. From 2010 - a low point for leveraged lending in the aftermath of the financial crisis - to mid-2019, leveraged lending grew from about $\$ 550$ billion to $\$ 1.2$ trillion. ${ }^{8}$ In that same period, the share of socalled covenant-lite ("cov-lite") leveraged loans jumped from under $5 \%$ to about $85 \% .{ }^{9}$ Cov-lite" loans are worrisome because they contain no financial maintenance covenants. Traditional loan agreements include covenants, which constrain various aspects of the borrower's operations or investments or financing decisions, in order to protect the lender from borrower risk taking over the life of the loan. A financial maintenance covenant requires the borrower to maintain a specified level of financial constraint, e.g., a certain ratio of debt to cash flow or earnings relative to interest expense. ${ }^{10}$

\footnotetext{
${ }^{4}$ Christopher James, Some Evidence on the Uniqueness of Bank Loans, 19 J. FIN. ECON. 217, 219 (1987) (showing a positive and statistically significant stock price response to the public announcement of bank loans, but a nonpositive response for publicly placed straight debt issues, and a negative and statistically significant response for debt privately placed with insurance companies and private placements and straight debt issues used to repay bank loans); George G. Triantis \& Ronald J. Daniels, The Role of Debt in Interactive Corporate Governance, 83 CAL. L. REV. 1073, 1100-01 (1995) (noting that the prospect of repeat business with the borrower firm may serve to align the bank's interests with those of equity holders as to investment policy and the firm's recovery); Sudip Datta, Mai Iskandar-Datta \& Ajay Patel, Bank Monitoring and the Pricing of Corporate Public Debt, 51 J. FIN. ECON. 435, 437 (1999) (finding that the presence of a preexisting bank loan reduces at-issue yield spreads for borrower firms' first public debt offerings by an average of 68 basis points, and the length of the bank/firm relationship is negatively related to at-issue yield spreads, consistent with the monitoring hypothesis); Douglas G. Baird \& Robert K. Rasmussen, Private Debt and the Missing Lever of Corporate Governance, 154 U. PA. L. REV. 1209 (2006). Firm value may also be enhanced through the certification effect of bank lending. A bank's decision to extend financing may signal the borrower firm's creditworthiness, offering useful information to securities markets and thereby enhancing the market value of the firm's equity.

${ }^{5}$ E.g., Greg Nini, David C. Smith \& Amir Sufi, Creditor Control Rights, Corporate Governance, and Firm Value, 25 REV. FIN. STUD. 1713 (2012) (finding that firm operating performance and stock price performance improve post-covenant-violation); Daniel Ferreira, Miguel A. Ferreira \& Beatriz Mariano, Creditor Control Rights and Board Independence, 73 J. FIN. 2385 (2018) (finding that the number of independent directors increases by about $24 \%$ following a covenant violation, that most new directors have ties to lenders, and that firms that appoint new directors post-violation are more likely to issue new equity and to decrease payouts, operational risk, and CEO cash compensation).

${ }^{6}$ See infra Part II.D.

7 Though there is no formal agreed-upon definition of what counts as a leveraged loan, a syndicated loan rated $\mathrm{BB}+$ or lower, or an unrated loan with an interest spread larger than 150 basis points (bps), is one common benchmark. Loan Pricing Corporation, PC definition. A BB+ rating is the highest grade of noninvestment-grade (or "speculative" grade) loan. Speculative grade loans are more likely to default than investment-grade loans. As of mid-2017, some $90 \%$ of loans issued in the U.S. are rated. S\&P GLOBAL, LEVERAGED COMMENTARY \& DATA (LCD): LEVERAGED LOAN PRIMER 8 (2020); available at https://www.lcdcomps.com/d/pdf/LCD\%20Loan\%20Primer.pdf. A basis point (bp) is 1/100 of a percentage point. So 150 bps is $1.5 \%$.

${ }^{8}$ Michelle Sierra, Leveraged Loan Market Size Doubles in Ten Year, Private Credit Explodes, ReUTERS (Dec. 23, 2019); Joe Rennison \& Colby Smith, Debt Machine: Are Risks Piling Up in Leveraged Loans?, FIN. TIMES (Jan. 21, 2019).

${ }^{9}$ See infra note 140 and accompanying text.

${ }^{10}$ The ratio of earnings to interest expense is commonly referred to as the Interest Coverage Ratio.
} 


\section{Do Lenders Still Monitor? \\ Leveraged Lending and the Search for Covenants}

With no financial maintenance covenants, a cov-lite loan is riskier than traditional loans. ${ }^{11}$ "Cov-lite takes away the canary in the coal mine for lenders." 12 Borrower firms seem happy to take up these risky loans, since the scarcity of covenants means fewer constraints on firms' operations and risk taking. At the same time, lender-investors appreciate the high interest rates and fees that come with risky loans. Moreover, as the costs of credit continue to decline as leveraged loan credit supply expands, lenders may enjoy less and less clout to demand covenant protection. The explosion of leveraged and cov-lite loans over the last decade naturally leaves regulators with misgivings about the quantum of risk taking in loan markets. ${ }^{13}$

In addition to the prospect of riskier loan markets, fewer and weaker covenants and an observed decline in lender interventions may portend weakened corporate governance. Financial economists have demonstrated empirically that judiciously crafted covenants can improve firm value. ${ }^{14}$ Through covenants and monitoring, lenders routinely exercise significant influence over corporate decision making. Weaker covenant protections and fewer lender interventions may therefore detract from effective corporate governance. ${ }^{15}$ Covenants screen borrowers ex ante. They also act as tripwires ex post to catch the attention of both the lender and the borrower's management. A covenant violation triggers a re-evaluation of the lender's constraints on management, and perhaps a renegotiation of loan terms, often well before a borrower firm approaches distress.

In this Article, I offer an updated and somewhat optimistic perspective on the leveraged loan market and lender governance. Despite important changes in lending markets that could plausibly exacerbate systemic risk and blunt the efficacy of lender governance, I show that lending practices have evolved to address the new risky lending. The steep growth of the leverage loan market may suggest that lenders have only weak leverage to demand contractual protections. But it turns out that lender governance persists, even as syndicated lending has become more complex.

One artifact of today's leveraged lending is the greater number and more diverse types of lenders involved in a leveraged loan deal as compared to traditional syndicated loans. Traditional syndications typically involved only banks, which typically held their loans to maturity. Today, banks still arrange syndicated loans, but they are as likely to sell the loans in secondary loan markets to non-bank institutional investors. Larger and more disparate lender groups make loan renegotiations ("workouts") more difficult. Different types of institutions hold differing priorities. A non-bank lending

\footnotetext{
${ }^{11}$ Cov-lite loans may, however, include so-called "incurrence" covenants, which require compliance with caps or financial ratios only when the borrower pursues a specified significant action, like issuing new debt or paying dividends or making an acquisition. See infra notes 138-140 and accompanying text.

12 Rennison \& Smith, supra note 8 (quoting Ruth Yang, managing director at S\&P Global Market Intelligence).

${ }^{13}$ See infra Part II.D.

${ }^{14}$ See supra notes 4-5 and accompanying text.

${ }^{15}$ Jeremy McClane, Corporate Non-Governance, 44 DEL. J. CORP. L. 1, 5 (2020).
} 


\section{Do Lenders Still Monitor? \\ Leveraged Lending and the Search for Covenants}

group may include collateralized loan obligations (CLOs), ${ }^{16}$ loan mutual funds, insurance companies, foreign investors, and pension funds, among others. The presence of heterogeneous lending institutions complicates the renegotiation of a loan agreement.

Another practice worrisome to regulators involves borrowers' potentially excessive leverage. Especially in the context of acquisitions and other extraordinary transactions, borrowers and lenders have taken to the practice of earnings "add-backs." The parties craft bespoke accounting provisions in their private loan contracts that allow for adjustments to projected earnings, which affect earnings-based financial covenants. With the justifiable aim of presenting a fair picture of the borrower's future earnings, the post-transaction borrower will adjust (augment) its earnings by adding back non-recurring items that affect cash flows or accruals-for example, one-time charges or expenses of the transaction. The firm's debt-to-earnings ratio is a typical leverage measure. Upward adjustments to earnings reduce the firm's reported leverage, which may create an excessively rosy picture. To the extent the borrower overstates adjusted earnings through add-backs, the leverage measure may become even less reliable.

Lenders have adapted to these concerns, however. Lenders have evolved new covenant structures to address the new and more complicated renegotiation frictions that arise with leveraged loans. Covenants have become more useful in three ways. First, loan arrangers have created socalled split control rights. An examination of individual cov-lite leveraged loans might suggest an absence of covenant constraints, but it turns out that very few leveraged loan deals are issued without maintenance covenants. Taking account of all the loan tranches in a given deal, the banks continue to enjoy the benefit of maintenance covenant constraints on the borrower firm. The typical leveraged loan deal includes a bank-sponsored loan, which almost always contains traditional financial covenants. ${ }^{17}$ At the same time, the bank group will arrange one or more additional loans for the borrower, but these loans will be sold to non-bank institutional lenders. ${ }^{18}$ In many deals, the bank-held loans and institutional loans will include identical covenants. But only the banks, and not the institutional lenders, enjoy the right to renegotiate covenants or waive violations. This split control effectively leaves the banks in charge of renegotiations with the borrower, reducing bargaining frictions. Traditional covenants in the banks' loan constrain the borrower firm, which is subject to the covenants in all its loans. The absence of maintenance covenants in a particular loan, then, does not mean that the borrower is free from covenant constraints. ${ }^{19}$

\footnotetext{
${ }^{16}$ A CLO is a securitization vehicle that buys slices of many syndicated loans, issuing securities to investors that are backed by the cash flows from the loans purchased. William W. Bratton \& Adam J. Levitin, A Tale of Two Markets: Regulation and Innovation in Post-Crisis Mortgage and Structured Finance Markets, 2020 U. ILL. L. REV. 47, 97-105 (explaining CLO structure and post-financial-crisis evolution of CLO indentures and federal regulation). See also infra notes 124-125 and accompanying text.

${ }^{17}$ This bank loan will typically be a revolving loan. The bank group may also extend an amortizing term loan. See infra note 127 and accompanying text.

${ }^{18}$ These loans sold to institutional lenders are typically non-amortizing term loans, which for reasons we discuss below, are riskier than the loans retained by banks. See infra Part II.B.

${ }^{19}$ See infra Part III.A.
} 


\section{Do Lenders Still Monitor? \\ Leveraged Lending and the Search for Covenants}

Second, with respect to add-backs, though upward earnings adjustments carry some risk of understating borrower leverage, new research suggests that permissive use of add-backs may improve the informativeness of EBITDA-based contract terms like financial covenants. ${ }^{20}$ Tailored accounting provisions for financial performance covenants in private loan agreements predict future cash flows better than GAAP-based measures. ${ }^{21}$ Better earnings information may eliminate noisy features of accounting earnings, such that add-backs may facilitate both tighter covenants and fewer false positive covenant violations. ${ }^{22}$

Lenders have recrafted covenants in another way as well. Over the course of the last two decades, covenants have become more efficient. This efficiency is driven largely by a turn away from balance sheet covenants in favor of cash flow covenants, which are much more discerning than balance sheet covenants. Cash flow covenants trigger false positives far less often than balance sheet covenants, with a negligible increase in false negatives. ${ }^{23}$ Financial covenants overall have also become less restrictive, both in terms of the number of covenants in a given loan and their tightness. Reported violations are correspondingly fewer. This should not be read as cause for concern, however. Rather than leaving borrower firms with no guardrails, covenant structures have instead become better at discriminating distress from non-distress situations. ${ }^{24}$ Efficient covenants minimize the sum of expected costs of false positives and false negatives.

The advent of split control rights, the informativeness of add-backs for predicting future cash flows to set financial covenants, and the evolution to efficient covenants suggest that it may be time to rework our understandings of the magnitude and direction of lender governance. Fewer and more lax covenants may not necessarily portend greater risk in the leveraged lending market. Lower levels of lender intervention do not necessarily herald weaker lender oversight.

My analysis proceeds as follows. In Part I, I explain the traditional structure of bank lending and the role of covenants and monitoring for lender governance. I describe banks' traditional and particular expertise in crafting covenants, monitoring borrowers, and renegotiating loan terms when the borrower falters. Traditional covenant structure meant tight covenants and pervasive monitoring, which differs dramatically from the evolved lender governance of split control rights and more efficient covenants. In Part II, I describe the evolution from traditional lending to a new and riskier loan market, driven in part by banking deregulation, in part by the advent of junk bonds and the 1980s leveraged buyout boom, in part by modernized bank capital rules, and in part by the advent of securitization. I also summarize the

\footnotetext{
${ }^{20}$ See infra Part III.B. EBITDA is one common earnings measure. It stands for Earnings Before Interest, Taxes, Depreciation, and Amortization.

${ }^{21}$ See id. GAAP stands for Generally Accepted Accounting Principles.

${ }^{22}$ For our purposes, a false positive occurs when a borrower violates a covenant even though only a low likelihood of distress exists See id.

${ }^{23}$ A false negative occurs when the borrower has a high likelihood of distress, but no covenant is triggered. See infra Part III.C.

${ }^{24}$ See id.
} 


\section{Do Lenders Still Monitor? \\ Leveraged Lending and the Search for Covenants}

misgivings of regulators and other debt market observers concerned with the new loan market's appetite for risk. In Part III, I explain the new lender governance regime. It features a number of lending contract innovationssplit control rights, add-back informativeness, and efficient covenants. ${ }^{25}$ These innovations facilitate lender governance and debt renegotiation in the face of larger loan syndicates with more dispersed lenders than in the past. I also discuss implications of the new lender governance. Part IV concludes.

\section{TRADITIONAL BANK LENDING: COVENANTS AND MONITORING}

This Part describes the structural features of bank lending that facilitate traditional bank monitoring. It introduces the tools banks use to constrain borrower risk taking and to facilitate monitoring-primarily an array of covenants that include affirmative and negative constraints and reporting and financial covenants. It then explains traditional covenant structure, both the setting of covenants and the bank's management of covenant violations.

\section{A. The Structure of Bank Lending}

Unlike equity holders, lenders do not enjoy unlimited upside with their debt investments in firms. Instead, lenders must content themselves with the regular periodic interest payments that their loan contracts memorialize, and also the repayment of principal when the loan matures. Because lenders enjoy no great upside from their lending, their natural obsession is to curb as much downside risk as possible, without drastically interfering with the borrower's ability to earn a respectable profit. By contrast, public company equity holders, who are typically diversified, are better off when their firms' managers pursue all available positive net present value projects. Because high returns to the firm arise only from firm managers taking high risks, equity holders sometimes push for risky gambits.

This divergence of interests between lenders and equity holders gets worked out in loan agreements. Lenders use covenants to constrain borrower risk taking, and borrowers and lenders will trade off interest rate against covenant strictness to reach a deal. A safer deal for the lender means a lower interest rate for the borrower. Typical affirmative covenants include obligations to purchase insurance and to comply with all applicable laws and regulations. Typical negative covenants include constraints on additional firm borrowing, payment of dividends or distributions to equity holders, and major asset sales. Financial covenants are also typical. For example, the lender may set a cap on the ratio of the borrower's debt-to-cash flow, in an effort to assure that the borrower will be able to maintain its periodic interest payments. ${ }^{26}$

\footnotetext{
${ }^{25}$ See infra Parts III.A and III.C, respectively.

${ }^{26}$ In addition to debt-to-cash flow, other common financial covenants include a fixed charge coverage ratio (a measure of the borrower's ability to cover all its fixed charges); a current ratio (the ratio of current assets to current liabilities); and a net worth covenant.
} 


\section{Do Lenders Still Monitor? \\ Leveraged Lending and the Search for Covenants}

Banks enjoy access to private information about their borrowers' business activities. Bank loan agreements typically demand regular reporting by the borrower, including financial statements and certificates attesting to the borrower's continuing compliance with financial covenants and other contractual obligations. Bank lenders also often require their borrower firms to keep their deposit accounts with the lending bank. This arrangement enables the lender to closely follow its borrower's aggregation and uses of cash in real time, giving the lender a clear window on the borrower's business activity. ${ }^{27}$ These institutional features of bank lending make banks especially effective monitors. Moreover, there is evidence that bank monitoring benefits not only the bank and other creditors; it may also improve firm value to the benefit of equity holders. Event studies consistently associate the public announcement of bank loans with positive abnormal stock returns for the borrower firm. ${ }^{28}$ The announcement is typically good news for shareholders, since the loan commits the bank to monitoring the borrower firm over the life of the loan. ${ }^{29}$

\footnotetext{
${ }^{27}$ Fisher Black, Bank Funds Management in an Efficient Market, 2 J. FIN. ECON. 323, 326 (1975) (explaining the informational advantages for a lender from maintaining its borrower's deposit account); Arnoud W. A. Boot, Relationship Banking: What Do We Know, 9 J. FIN. InTERMED. 7, 11 (2000); Eugene F. Fama, What's Different About Banks?, 15 J. MONETARY ECON. 29, 37-38 (1985). Bank lenders also typically enjoy wide access to their borrowers' books and records. A bank may also have a representative on its borrower's board of directors, which enables the bank to obtain soft information about the borrower. Tung, supra note 3 , at 138-40.

${ }^{28}$ See Christopher James, Some Evidence on the Uniqueness of Bank Loans, 19 J. FIN. ECON. 217, 219 (1987); Myron B. Slovin, Shane A. Johnson, \& John L. Glascock, Firm Size and the Information Content of Bank Loan Announcements, 16 J. BANKING \& FIN. 1057, 1058 (1992); Ronald Best \& Hang Zhang, Alternative Information Sources and the Information Content of Bank Loans, 48 J. Fin. 1507, 1511 (1993); Matthew T. Billett, Mark J. Flannery, \& Jon A. Garfinkel, The Effect of Lender Identity on a Borrowing Firm's Equity Return, 50 J. FIN. 699, 700 (1995). A related literature suggests that nonbank private debt may also bring bank-like benefits to equity holders. These studies show a positive stock price reaction to announcements of nonbank private debt placements, with no statistical difference between announcements of bank debt versus nonbank private debt. See Dianna C. Preece \& Donald J. Mullineaux, Monitoring by Financial Intermediaries: Banks Versus Nonbanks, 8 J. FIN. SERV. RES. 193, 199 (1994); Billet, et al., supra.

${ }^{29}$ See Sudha Krishnaswami, Paul A. Spindt \& Venkat Subramaniam, Information Asymmetry, Monitoring, and the Placement Structure of Corporate Debt, 51 J. FIN. ECON. 407, 409 (1999) (finding that firms with greater growth prospects - and therefore greater debt-related moral hazard problems - rely more heavily on private debt than public debt, and attributing this result to the monitoring advantages of private debt); Scott L. Lummer \& John J. McConnell, Further Evidence on the Bank Lending Process and the Capital-Market Response to Bank Loan Agreements, 25 J. FIN. ECON. 99, 101 (1989) (finding excess stock returns almost exclusively around the announcement of loan renewals, but not new loans, and concluding that the value to shareholders comes not from the initial screening of prospective borrowers, but from private information the bank gleans during the course of its relationship with the borrower, consistent with a monitoring theory).

This positive stock market reaction may also arise from a complementary source. The bank's decision to extend credit may signal that it has positive private information about the firm-i.e., the bank resolves adverse selection problems for the stock market. See Best \& Zhang, supra note 28; Charles J. Hadlock \& Christopher M. James, Do Banks Provide Financial Slack?, 57 J. FIN. 1383 (2002); Wayne H. Mikkelson \& M. Megan Partch, Valuation Effects of Security Offerings and the Issuance Process, 15 J. FIN. ECON. 31 (1986); Stewart C. Myers \& Nicholas S. Majluf, Corporate Financing and Investment Decisions When Firms Have Information That Investors Do Not Have, 13 J. FIN. ECON. 187 (1984). The crossmonitoring benefits may run in favor of the bank as well. One study finds that bank debt is cheaper for firms with publicly traded shares or investment-grade public debt outstanding. James R. Booth, Contract Costs, Bank Loans, and the Cross-Monitoring Hypothesis, 31 J. FIN. ECON. 25 (1992).
} 


\section{Do Lenders Still Monitor? \\ Leveraged Lending and the Search for Covenants}

\section{B. Traditional Covenant Structure}

Covenant constraints in the initial loan agreement both screen borrowers ex ante and curb managers' discretion from the inception of the lending relationship. Subsequent covenant violations trigger lender scrutiny and the possibility of further constraints on management and operations.

\section{Covenant Setting to Control Agency Costs}

Empirical studies show that the structuring of initial covenants responds to firm characteristics that affect credit risk, and that managers alter their behavior in response to covenant constraints. Lender influence commences from the very beginning of the lending arrangement.

Among other fears, lenders would worry that once credit is extended, firm managers may favor their own interests or the interests of equity holders over those of creditors. Managers might, for instance, substitute risky projects for more conservative ones, since in the presence of debt, diversified equity holders do better with the former than the latter. Managers might even spend free cash on negative net present value projects, either to build empires for their own benefit or to improve equity holders' upside returns. The finance literature has identified situations in which these agency costs may be most troublesome. Financial distress, for example, heightens the conflict between debt and equity.

Traditional covenant structure responds to those perils. Firms with greater risk of financial distress - smaller, more highly levered, more volatile firms, and firms with highly liquid assets - are more likely to have covenants in their lending agreements. By contrast, loans to firms with a higher ratio of tangible assets to total assets are less likely to include covenants. ${ }^{30}$ This makes sense as tangible assets are easier to value and easier to liquidate than intangible assets in the event of the firm's default. Firms with intangible assets and growth opportunities are riskier because realization of the value of these opportunities depends on discretionary future investment by the firm. Specific covenants address this sort of risk: high growth firms are more likely to attract demands for security, financial ratio covenants, and covenants restricting dividends. ${ }^{31}$ Moreover, historically, private lenders set covenants fairly tightly relative to the variability of the underlying accounting measure, adjusting covenant "slack" to account for this variability for each borrower. ${ }^{32}$ Tighter covenants were also associated with lower borrowing costs, consistent with the proposition that lenders valued these stricter limits and their effects on borrower behavior. ${ }^{33}$

\footnotetext{
${ }^{30}$ Michael Bradley \& Michael R. Roberts, The Structure and Pricing of Corporate Debt Covenants, 5 Q.J. Fin. 1 (2015) (analyzing commercial loans made from 1993-2001, as reflected in Loan Pricing Corporation's Dealscan database).

${ }^{31} I d$. at 19, tbl. 6 (relying on the market-to-book ratio as a measure of growth).

32 Ilia D. Dichev \& Douglas J. Skinner, Large-Sample Evidence on the Debt Covenant Hypothesis, $40 \mathrm{~J}$. ACCT. RES. 1091, 1093 \& 1106-07 (2002).

${ }^{33}$ Cem Demiroglu \& Christopher M. James, The Information Content of Bank Loan Covenants, 23 REV. FIN. STUD. 3700 (2010). Tighter covenants may also simply reflect the lender's higher confidence in the
} 


\section{Do Lenders Still Monitor? \\ Leveraged Lending and the Search for Covenants}

Covenants also likely affect managers' behavior. Despite the fact that technical covenant violations are common and do not typically result in punitive lender action, managers cannot count on this. A violation triggers the lender's legal right to demand immediate repayment of the entire debt, and even though acceleration is unlikely, a violation might always cause some curtailment of managerial discretion through the bank's intervention. Even for healthy firms in the best of situations, there is a hassle factor: a violation requires managers to explain. It triggers review by the bank and may impose additional reporting burdens on borrower management, which is put to the task of defending its forecasts and strategies. ${ }^{34}$ All this takes time away from running the company. Banks also often charge a fee for a waiver or modification of the loan. Managers have incentive to comply.

Though measuring the effects of loan covenants on managerial behavior may be a bit tricky, studies tend to confirm that covenants have real effects. When we look at firm performance following the loan's inception, we find some telling patterns. Comparing quarter-end accounting measures with the associated covenants, one study finds an unusually small number of loan quarters with borrower performance slightly beyond covenant thresholds - that is, in violation - while an unusually large number cluster just shy of the violation point. ${ }^{35}$ In other words, there is a significant discontinuity in the distribution of firms' performance on accounting measures constrained by covenants. Moreover, the discontinuous pattern becomes more pronounced over the life of the loan. This longitudinal dimension is important. Clustering in general, while consistent with the view that covenants constrain managers, does not necessarily rule out the anticipatory contracting explanation - that covenants are set in order to anticipate the borrower's future performance, but not to constrain it. When lenders set tight covenants, we would expect to see some clustering near the covenant threshold. Anticipatory contracting could plausibly account for clustering generally or discontinuity in the quarters immediately following the loan's inception. However, the persistence and increased prominence of this discontinuous pattern in a loan's later years is difficult to explain as an artifact of anticipatory contracting. ${ }^{36}$ Instead, the pattern suggests that covenants have real bite: firms attempt to manage in response to covenant constraints.

\section{Covenant Violations}

Not surprisingly, poor performance and covenant violations typically cause lenders to monitor their borrowers more closely and perhaps to actively intervene in managerial decisionmaking. Financial covenant violations are

\footnotetext{
borrower's future performance. See id. Stock price reactions to public announcement of loans are also larger for loans with tighter covenants. Id.

${ }^{34}$ Dichev \& Skinner, supra note 32, at 1096 (describing the hassle factor).

${ }^{35} \mathrm{Id}$. at 1111-12 (investigating current ratio and net worth covenants).

${ }^{36} I d$.
} 


\section{Do Lenders Still Monitor? \\ Leveraged Lending and the Search for Covenants}

common, and they do not typically presage financial distress, ${ }^{37}$ though they might trigger some lender response. Over a ten-year period, according to one study, a quarter to almost a third of all public companies violated a financial covenant, ${ }^{38}$ and this may be a lower bound, as methodological constraints suggest that many technical violations may go undetected. ${ }^{39}$ Violations rarely lead to payment default or acceleration of the loan. A violation will trigger the lender's scrutiny, and firm managers might be tasked to justify the firm's strategies and forecasts. Ultimately, however, the lender most often waives the violation. ${ }^{40}$

The second most likely lender response is to impose additional constraints on the borrower. ${ }^{41}$ More serious measures such as a reduction in credit, an increase in interest rate, or a requirement of additional collateral are less likely, ${ }^{42}$ though of course, if the firm's slide were to continue, the bank would resort to these and other more aggressive measures. ${ }^{43}$

Covenants are used primarily, then, not as a device to force the borrower's immediate repayment of the loan, even though the lending agreement provides for that remedy. Instead, covenants serve as trip wires that signal the need for creditor attention. When the wire is tripped, the lender steps in to update its information about the borrower. The lender communicates with management and examines the firm's financial position and internal forecasts. In most cases, tripping the wire does not ultimately result in any punitive response by the creditor. But it does command the

\footnotetext{
${ }^{37}$ Id. at 1093; Sudheer Chava \& Michael R. Roberts, How Does Financing Impact Investment?: The Role of Debt Covenants 2 (draft Aug. 2007); available at $\mathrm{http}: / / \mathrm{ssrn}$.com/abstract=854324.

${ }^{38}$ Michael R. Roberts \& Amir Sufi, Control Rights and Capital Structure: An Empirical Investigation, $64 \mathrm{~J}$. FIN. 1657, 1663-1664 \& tbl. I (2009) (finding that for population of U.S. public companies between 1996 and 2005, more than one quarter violated a financial covenant, and for companies with an average leverage ratio of at least 5 percent, the percentage increases to 30\%). See also Dichev \& Skinner, supra note 32, at 1093 (finding that with a Dealscan sample of private loans from 1986-99, violations occur in about 30 percent of all loans); Chava and Roberts, supra note 37, at 11 (finding that 37 percent of firms subject to a current ratio covenant and 25 percent of firms subject to a net worth covenant during the period 1994-2005 committed a violation of the respective covenant).

${ }^{39}$ One lending officer at a prominent insurance company reports that in a given year, the company will receive on average one request for a covenant modification for each loan on its books. Edward D. Zinbarg, The Private Placement Loan Agreement, FIN. ANALYSTS J., July-Aug. 1975, at 35 (discussing private placement lenders).

${ }^{40}$ V. Gopalakrishnan \& Mohinder Parkash, Borrower and Lender Perceptions of Accounting Information in Corporate Lending Agreements, 9 ACCT. HORIzONS 13, 20 (1995) (surveying chief financial officers of Fortune 500 companies, chief lending officers of the largest 100 banks, and the heads of private placement departments at the top 100 insurance companies, with more than 95 percent of both borrowers and lenders indicating a medium or high probability of a waiver). According to one lender's report, more than 95 percent of requests for covenant modification are granted with no quid pro quo: "the vast majority of corporate requests are perfectly reasonable and do not increase [lender] risk materially." Zinbarg, supra note 39.

${ }^{41}$ Seventy-five percent of borrowers and 59 percent of lenders indicate a medium to high probability of additional constraints. Gopalakrishnan \& Parkash, supra note 40, at 20, 21 tbl.3.

${ }^{42}$ Id.; Roberts \& Sufi, supra note 38, at 1688, 1689 tbl. IX (noting from SEC filings for a random sample of 500 initial covenant-violating firms that $24 \%$ of violations resulted in reduced credit availability; $15 \%$ resulted in increases in interest spread; $7 \%$ resulted in the lender requiring additional collateral; and that in the aggregate, $32 \%$ of lenders took at least one of these actions, while $63 \%$ of violations resulted in a waiver without additional action).

${ }^{43}$ The most drastic remedies of termination of the agreement and acceleration of the debt are, of course, the least common. Over 76 percent of Fortune 500 borrowers and more than 90 percent of their lenders assign a zero or low probability to these outcomes. Gopalakrishnan \& Parkash, supra note 40, at 20-21 tbl.3.
} 


\section{Do Lenders Still Monitor? \\ Leveraged Lending and the Search for Covenants}

lender's attention and gives the lender the option to act, depending on what its investigation shows.

\section{Lender Governance}

Besides simply shoring up a borrower's creditworthiness with extra collateral or reduced credit availability once a non-trivial violation occurs, a lender may additionally force important changes in the way the firm operates. The lender may demand crucial changes to financial policy or investment policy. In a drastic situation, the lender may force the CEO's replacement.

The lender's influence on financial policy, of course, begins at the loan's inception. Almost all loan agreements limit the borrower's ability to incur additional debt. ${ }^{44}$ The restriction typically places a cap on a debt-related ratio, using a debt measure as numerator and a measure of earnings, cash flow, or capitalization as the denominator. ${ }^{45} \mathrm{~A}$ covenant violation often invites further constraints by the lender. In one study, normalizing firm borrowing as a percentage of assets, a covenant violation results in a $0.7 \%$ decrease in average firm borrowing in the quarter immediately following the violation. This is an economically significant drop. ${ }^{46}$ It also endures.

Like financial policy, investment policy is a crucial aspect of managers' strategic decision making, effectively placing the firm's bets on the future. Banks typically enjoy meaningful influence over these decisions, since covenant constraints allocate control rights over investment policy, making it contingent on the firm's performance. For example, one-third of public company loan agreements contain a capital expenditure covenant, and over a ten-year sample period, $42 \%$ of public firms face a capital expenditure restriction at some point. ${ }^{47}$ Firms facing a new capital expenditure restriction experience a decline in investment $15-20 \%$ larger than firms not facing a new restriction. ${ }^{48}$ Not surprisingly, such restrictions are quite sensitive to firm performance. A covenant violation, an increase in credit risk (as measured by the borrower's debt-to-cash-flow ratio), or a ratings downgrade increases the

\footnotetext{
${ }^{44}$ Roberts \& Sufi, supra note 38, at 1663 (noting that almost $90 \%$ of loan agreements in their sample contain an explicit or implicit restriction on the borrower's total debt).

${ }^{45}$ Over 79 percent of loan agreements in the sample contain such a covenant. $I d$. at tbl. I. For example, one agreement defines a leverage ratio:

"Leverage Ratio" mean, on any date, the ratio of (a) Total Indebtedness as of such date to (b) Consolidated EBITDA for the period of four consecutive quarters of the Company ended on such date.

Further down, the agreement caps the ratio at 3:1.

SECTION 6.12. Leverage Ratio. The Company will not permit the Leverage Ratio as of the last day of any fiscal quarter to exceed 3.00 to 1.00 .

Credit Agreement Dated as of November 14, 2006, Among Amerisourcebergen Corporation et al., $\S \S 6.11$, 6.12 (on file with author). "EBITDA" is earnings before interest, taxes, depreciation, and amortization.

${ }^{46}$ Compare the effect of a change in firm size, which is the single most powerful predictor of net borrowing. A two-standard-deviation reduction in the size of the firm results in only a $0.52 \%$ reduction in net borrowing per quarter. In relative terms, the $0.7 \%$ drop moves the firm from the $65^{\text {th }}$ to the $35^{\text {th }}$ percentile of the withinfirm net debt issuance distribution. Id. at 1659 .

${ }^{47}$ Greg Nini, David C. Smith \& Amir Sufi, Creditor Control Rights and Firm Investment Policy, 92 J. FIN. ECON. 400, 405 (2009).

${ }^{48} \mathrm{Id}$. at 413 .
} 


\section{Do Lenders Still Monitor? \\ Leveraged Lending and the Search for Covenants}

likelihood that the borrower will face an investment restriction. For example, a firm that suffers a ratings downgrade from the lowest Standard \& Poor's investment grade $(\mathrm{BBB})$ to the highest speculative grade $(\mathrm{BB})$ experiences a $21 \%$ increase in the likelihood of incurring a capital expenditure restriction. ${ }^{49}$ A similar increase in the likelihood of facing a capital expenditure restriction befalls the borrower violating a covenant. ${ }^{50}$ While violating firms also commonly face interest rate increases, demands for collateral, and dividend restrictions, the elasticity of the capital expenditure restriction with respect to a violation is significantly larger than the elasticity of other loan terms. ${ }^{51}$

Finally, it is important to highlight the uncommon but sometimes necessary step of replacing a borrower firm's CEO. Though canonical accounts of change in the C-suite typically view boards of directors as the central players, as a practical matter, lender influence may be at least as important in many cases. The pattern is familiar. Having chosen a CEO who subsequently oversaw excellent results over a number of years, a board may be slow to recognize when the CEO's magic has run out. Having invested in the effort to handpick a CEO, and then cheered her success for a time, directors may naturally be reluctant later to second-guess their decision or consider the possibility of a replacement. "Once it has installed or chosen to retain a CEO, the board is motivated to trust the CEO more than it should." 52 Lenders, of course, are less likely to suffer from this commitment bias. ${ }^{53}$ They were not formally (and likely not even informally) a part of the process that chose this CEO. So the lenders may be able to assess the borrower's situation with more dispassion than the directors who backed the now-faltering CEO. When the borrower gets into trouble, and shareholder pressure and the market for corporate control are insufficient to effect a CEO change, lender influence may be key. The firm's downward spiral will likely trigger covenant violations, which shifts control to lenders. And though lenders of course do not formally decide the existing CEO's fate nor tap her successor, lenders' influence is felt. As earlier noted, ${ }^{54}$ once lenders enjoy the right to accelerate the entire debt, a number of less drastic measures are also on the table. CEO replacement is one. ${ }^{55}$

The familiar story of Krispy Kreme offers an illustration. Scott Livengood served as Krispy Kreme's CEO from 1998-2005. He had worked for the company for several decades, having come up through the ranks of the HR department. His devotion to and enthusiasm for the company were legend. His wedding cake, for example, was made entirely from Krispy

\footnotetext{
${ }^{49} I d$. at 401.

${ }^{50} \mathrm{Id}$. (noting that a capital expenditure restriction is $20 \%$ more likely with a covenant violation).

${ }^{51} I d$. at 411 \& tbl. 6.

${ }^{52}$ Donald C. Langevoort, Resetting the Corporate Thermostat: Lessons from the Recent Financial Scandals About Self-Deception, Deceiving Others and the Design of Internal Controls, 93 GEO. L.J. 285, 294 (2004).

${ }^{53}$ See, e.g., Barry M. Staw, Knee-Deep in the Big Muddy: A Study of Escalating Commitment to a Chosen Course of Action, 16 OrG. BeHAV. \& HuM. PERFormanCE 22, $22-44$ (1976).

${ }^{54}$ Supra, Part I.2.

${ }^{55}$ Lenders generally need to be gingerly about expressing their druthers too forcefully in this context.
} 


\section{Do Lenders Still Monitor? \\ Leveraged Lending and the Search for Covenants}

Kreme donuts. ${ }^{56}$ He took the company through its IPO in 2000. The ensuing three years saw the company's stock price quadruple, and headcount increased by 7,000. ${ }^{57}$ Then the second largest doughnut chain in the country, Krispy Kreme became "a high-profile, closely watched darling in retail and investor circles after opening dozens of freestanding stores around the country." The company had attained "a cult-like following." 58

The "darling" status was somewhat short-lived, however. By 2004, Krispy Kreme's popularity had waned. Livengood initially blamed the lowcarb craze for the company's declining sales, but others believed the decline was the result of improvident expansion - the opening of too many stores too quickly without adequate support and planning. ${ }^{59}$ Its accounting practices also triggered an SEC investigation, ${ }^{60}$ which left the company vulnerable to a default declaration by its lenders for failing to file financial reports as required under the company's $\$ 150$ million loan agreement. The company had borrowed $\$ 91$ million under the facility as of October 2004. By January 2005 , the lenders had cut off further borrowing, leaving the company and lenders to negotiate serial extensions of the default date while the company searched for alternative financing. ${ }^{61}$ By this point, needless to say, the lenders were well positioned to dictate terms. The company announced Livengood's retirement as CEO, board chair, and director in a January press release. ${ }^{62}$

$$
* * *
$$

Having explained the mechanics of traditional lender governance, the next Part explains the evolution of loan markets over the past few decades, a period that has witnessed tremendous changes in debt markets, lending

${ }^{56}$ Mark Maremont \& Rick Brooks, Once-Hot Krispy Kreme Ousts Its CEO Amid Accounting Woes, WALL ST. J. (Jan. 19, 2005); available https://www.wsj.com/articles/SB110605594997928805\#: :text=The\%20man\%20who\%20transformed\%20 Krispy,woes\%20and\%20a\%20federal\%20probe [https://perma.cc/X8QU-RSF7].

${ }^{57}$ Andy Serwer, The Hole Story: How Krispy Kreme Became the Hottest Brand in America, FoRTUNE (July 7, 2003); available at https://archive.fortune.com/magazines/fortune/fortune archive/ 2003/07/07/345535/index.htm [https://perma.cc/Z642-FGAM].

${ }^{58}$ Lynne Miller, Krispy Kreme Replaces Top Bosses, SUPERMARKET NewS (Jan. 24, 2005); available at https://www.supermarketnews.com/archive/krispy-kreme-replaces-top-bosses\#comment-0.

${ }^{59} \mathrm{Id}$.

${ }^{60}$ Floyd Norris, Krispy Kreme Picks Turnaround Specialist, N.Y. TIMES (Jan. 19, 2005); available at https://www.nytimes.com/2005/01/19/business/krispy-kreme-picks-turnaround-specialist.html. At the same time, Krispy Kreme announced that it would delay indefinitely the filing of its fiscal 2004 financial statements, which would have to be restated, with the expectation that net income would be cut by as much as $26 \%$ for the fiscal fourth quarter after correction of accounting errors. Mark Maremont \& Rick Brooks, Fresh Woes Batter Krispy Kreme; Doughnut Firm to Restate Results, Delay SEC Filing; Shares Take a 15\% Tumble, Wall St. J. (Jan. 5, 2005); available at https://www.wsj.com/articles/SB110484914816116399.

${ }^{61}$ By March 25, 2005, Krispy Kreme had not found an alternative lender, though it did succeed in pushing its default date back to April 11, 2005. Associated Press, Krispy Kreme Gets Extension, N.Y. TIMES (Mar 26, 2005); available at https:/www.nytimes.com/2005/03/26/business/krispy-kreme-gets-extension.html.

${ }^{62}$ Press Release, Krispy Kreme Doughnuts, Inc., Krispy Kreme Announces Management Changes (Jan. 18, 2005); available at http://phx.corporate-ir.net/phoenix.zhtml?c=120929\&p-irol-newsArticle\&ID=663642. The press release also noted the company's recent steep sales declines: For the eight weeks ended December 26,2004 , systemwide and average weekly sales per factory store decreased by approximately $18 \%$ and $25 \%$, respectively, from the prior year's corresponding weeks. Id.

The press release also announced the appointment of a consulting and crisis management group to run the company, that the company was barred from further borrowing under its $\$ 150$ million credit facility, and that its lenders had agreed to defer the calling of a default pending further discussion. $I d$. 


\section{Do Lenders Still Monitor? \\ Leveraged Lending and the Search for Covenants}

practices, and the uses of debt, as well as the emergence of new debt instruments.

\section{THE NEW LOAN MARKETS}

New loan markets have emerged in the face of major changes to the lending environment. I begin by describing traditional syndicated bank lending. I then explain important changes in banking regulation and bank lending markets that led to the skyrocketing supply and demand for leveraged loans. Financial services deregulation that began in the late 1970s led to increased competition to make loans. At the same time, with the leveraged buyout boom of the 1980s, firms and investors became more comfortable with riskier capital structures, happy to rely on risky debt-both bank loans and high-yield bonds - to finance massive takeovers. Modernization of bank capital rules also ultimately helped pushed banks toward an originate-todistribute model of lending. Together these various influences propelled a market for the new risky loans.

\section{A. $\quad$ Traditional Syndicated Bank Lending}

The typical bank loan to a public company is syndicated. A large money center bank - the "lead" bank — negotiates the loan with the borrower while it assembles the lending syndicate. 63 The lead bank takes the laboring oar in performing due diligence on the borrower, and prospective syndicate members typically rely on the lead bank's documentation in performing their credit analyses. ${ }^{64}$ Once the syndicate is assembled and the loan is in place, the lead bank-which typically holds the largest stake in the loan ${ }^{65}$ - is granted wide powers to act as agent for the syndicate, for which the lead bank is paid a fee. ${ }^{66}$ It takes the lead in administering the loan, monitoring the

63 See Amir Sufi, Information Asymmetry and Financing Arrangements: Evidence From Syndicated Loans, 62 J. FIN. 629, 633 (2007); Kamphol Panyagometh \& Gordon S. Roberts, Private Information, Agency Problems and Determinants of Loan Syndications: Evidence From 1987-1999, at 4 (Apr. 25, 2002) (unpublished manuscript, on file with author) available at http://ssrn.com/abstract $=310003$. The arranging bank may underwrite the loan as well, in effect committing to extend the specified loan even before the formation of the syndicate is complete.

64 See Barry Bobrow, Mercedes Tech, and Linda Redding, An Introduction to the Primary Market, in THE HANDBOOK OF LOAN SYNDICATIONS AND TRADING 155, 179 (Allison Taylor \& Alicia Sansone eds., 2007); Panyagometh \& Roberts, supra note 63, at 5; Katerina Simons, Why Do Banks Syndicate Loans?, NEW ENGLAND ECON REV. 45, Jan.-Feb. 1993, at 47, available at https://www.bostonfed.org//media/Documents/neer/neer193c.pdf.

65 See Baird \& Rasmussen, supra note 4, at 1244; Sufi, supra note 63, at 633. But see Kristian Blickle, Quirin Fleckenstein, Sebastian Hillenbrand \& Anthony Saunders, The Myth of the Lead Arranger's Share, FED. RES. BANK NY, Staff Rpt. No. 922 (May 2020) (using Shared National Credit Program data).

${ }_{66}$ The credit agreement spells out these relations among syndicate members. See Richard Wight, Warren Cooke, \& Richard Gray, Understanding the Credit Agreement, in THE HANDBOOK OF LOAN SYNDICATIONS AND TRADING supra note 64, at 209,354. As competition among banks intensified and league tables became a popular device for "keeping score" among banks and ranking them, lead arrangers began carving out new distinguishing roles and accompanying titles to induce participation in their syndicates. New-and largely ceremonial-titles include "administrative agent," "syndication agent," "documentation agent," and "managing agent," which may also indicate some sharing of functions that had traditionally been performed by the sole lead bank. See Steve Miller, Players in the Market, in THE HANDBOOK OF LOAN SyNDICATIONS AND TRADING supra note 64, at 47, 50. 


\section{Do Lenders Still Monitor? \\ Leveraged Lending and the Search for Covenants}

borrower and communicating with firm management on behalf of the syndicate, and disseminating information within the syndicate. ${ }^{67}$ When a borrower violates a covenant or defaults, the lead bank plays a central role in investigating and recommending a course of action to the syndicate. 68

As the arranger for the loan and its primary monitor and administrator, the lead bank typically enjoys informational advantages over other syndicate members. One might therefore worry that the lead bank could behave opportunistically toward syndicate members - for example by syndicating poor quality loans or shirking on its monitoring duties. As the agent for the syndicate, the lead bank reaps only a pro rata benefit from diligent monitoring - sharing with the entire lender group-while it enjoys all the benefits from shirking. ${ }^{69}$ Lead banks and other private lenders may also sell their loans in liquid secondary loan markets. This ready exit option may create moral hazard, encouraging lax credit analysis in the origination process or weaker monitoring after the loan is made. ${ }^{70}$

Traditionally, lead banks had reputational stakes in their treatment of syndicate members. Far from behaving opportunistically, lead banks would in fact syndicate loans of higher ex ante quality in larger proportions, ${ }^{71}$ and would retain larger proportions of riskier loans. ${ }^{72}$ Lead banks would also syndicate a larger proportion of loans to borrowers whose creditworthiness could be expected to hold up over time, as measured by ex post credit ratings. ${ }^{73}$ More generally, lead banks' reputations as faithful agents improved

67 Sufi, supra note 63, at 632-33.

68 Michael R. Roberts \& Amir Sufi, Renegotiation of Financial Contracts: Evidence from Private Credit Agreements, 93 J. FIN. ECON. 159 (2009).

69 For example, the lead bank might decide to devote more resources to originating new loans - an activity that generates fees for the lead bank - rather than monitoring existing syndicated loans, as to which risk is shared.

70 See Gary B. Gorton \& George G. Pennacchi, Banks and Loan Sales: Marketing Nonmarketable Assets, 35 J. MONETARY ECON. 389, 391 (1995) (discussing moral hazard in the secondary loan market). Given originating lenders' likely informational advantages over secondary market purchasers, it might not be surprising if lower quality loans were more likely to trade than those of higher quality. Especially given the emerging "originate-to-distribute" model of syndication - in which the lead arranger anticipates selling large portions of a given loan to institutional investors in secondary markets shortly after originationarrangers may be less concerned about careful credit analysis or subsequent monitoring than if they expected to hold the loans for longer periods. See Antje Berndt \& Anurag Gupta, Moral Hazard and Adverse Selection in the Originate-to-Distribute Model of Bank Credit (Oct. 24, 2008) (unpublished manuscript, on file with author), available at http://ssrn.com/abstract=1290312; Greg Nini, How Non-Banks Increased the Supply of Bank Loans: Evidence from Institutional Term Loans (Mar. 18, 2008) (unpublished manuscript, on file with author), available at $\mathrm{http}: / / \mathrm{ssrn} . \mathrm{com} / \mathrm{abstract}=1108818$ (documenting the boom in syndicating leverage loan tranches to nonbank institutional investors).

71 See Steven A. Dennis \& Donald J. Mullineaux, Syndicated Loans, 9 J. Fin. InTERMEDIATION 404, 424 (testing for ex ante quality); see also Kamphol Panyagometh \& Gordon S. Roberts, Loan Syndicate Structure: Evidence from Ex Post Risk 3-4 (Jan. 14, 2008) (unpublished manuscript, on file with author), available at $\mathrm{http}: / / \mathrm{ssrn}$.com/abstract $=1083707$ (finding that lead banks syndicate greater proportions of loans to ex post higher quality borrowers as measured by bond ratings).

72 See Simons, supra note 64, at 49 tbl.3 (showing that the proportion of a syndicated loan retained by the lead bank increases with the severity of the borrower's credit problems, as subsequently determined by bank examiners' loan quality classifications); Sufi, supra note 63, at 633. For more opaque borrowers, that require greater due diligence and monitoring, the lead bank generally retains a larger share of the loan and forms a more concentrated syndicate, with lenders that are "closer" to the borrower both geographically and in terms of prior lending relationships. $I d$.

73 Panyagometh \& Roberts, supra note 71, at 24. 


\section{Do Lenders Still Monitor? \\ Leveraged Lending and the Search for Covenants}

their ability to arrange syndications. ${ }^{74}$ These findings suggest that lead banks valued their reputations, which induced them to monitor conscientiously despite the risk diversification from syndication.

The lead bank also typically did not sell its stake, ${ }^{75}$ preferring instead to preserve its relationships with both the borrower and its syndicate members, who not only depended on the lead bank for monitoring services, ${ }^{76}$ but agreed to join the syndicate relying at least in part on the lead bank's continuing involvement in the loan. Lead banks also often constrained resale by syndicate members, imposing requirements that might include lead bank and even borrower consent. ${ }^{77}$ Lead banks and borrowers could plausibly be concerned about syndicate size and composition, since all other things being equal, a larger syndicate makes collective decisionmaking more difficult. ${ }^{78}$ Holdout problems also increase with syndicate size, ${ }^{79}$ which may be especially troubling when the borrower's distress requires a modification of the loan. ${ }^{80}$

Lenders in general also anticipated potential secondary market purchasers' concerns about moral hazard with respect to monitoring, as well as adverse selection. ${ }^{81}$ Selling lenders would not always sell their entire stake in a loan, often retaining a portion to assure purchasers of both the quality of the loan and the seller's continuing stake in monitoring the borrower. Consistent with this implicit assurance, loan sellers typically retained larger portions of riskier loans. ${ }^{82}$ Loans that were ultimately sold also contained more restrictive covenants than loans that were not sold. ${ }^{83}$ These tighter covenants, by putting borrowers on a tighter leash, helped address both

74 See Dennis \& Mullineaux, supra note 71, at 407 (finding that lead banks' success in syndicating larger percentages of their loans is positively associated with reputational measures).

75 Baird \& Rasmussen, supra note 4, at 1244.

76 See Panyagometh \& Roberts, supra note 71, at 3 (describing the lead bank's role as the delegated monitor for the syndicate); Sufi, supra note 63, at 632 (noting the lead arranger's role as the syndicate's primary monitor);. For their part, borrowers generally expect and prefer a durable relationship with their lead bank, which has specialized knowledge of its borrowers' business and financial condition. If the lead bank exits by selling its loan, the borrower may be left with a different agent bank that it has never worked with and that may not be to its liking.

77 Sang Whi Lee \& Donald J. Mullineaux, Monitoring, Financial Distress, and the Structure of Commercial Lending Syndicates, 33 FIN. MGMT. 107, 111 (2004). Forty-four percent of the transactions in their sample of syndicates loans from 1987-1995 included a requirement for lead bank consent for loan resale. $I d$. at 117 .

78 Modification of a syndicated loan requires a vote among the members. For major changes - in principal, interest, maturity, or collateral - unanimity is typically required. For technical violations or covenant waivers, a simple majority or supermajority will typically suffice. See Sufi, supra note 63, at 633.

79 Oliver Hart, Firms, Contracts, and Financial Structure (1995).

80 See Lee \& Mullineaux, supra note 77, at 111. The effect of loan sale restrictions may be ambiguous in terms of reducing holdout problems, however. Originating syndicates tend to be larger and loan concentrations lower for loans with resale constraints. These liquidity constraints make the loan less attractive to participants, who take smaller shares as a result. $I d$. at 120-21.

81 That is, potential purchasers may fear that sellers only want to dump their bad loans.

82 Gorton \& Pennacchi, supra note 70, at 408 \& tbl.5; cf. Berndt \& Gupta, supra note 70 (finding evidence of bank moral hazard insofar as firms whose loans are sold have worse risk adjusted stock returns over the three years following the loan sale compared to firms whose loans are not sold).

83 Steven Drucker \& Manju Puri, On Loan Sales, Loan Contracting, and Lending Relationships 2 (FDIC Ctr. for Fin. Research Working Paper No. WP 2007-04,2007), available at http://ssrn.com/abstract=920877. 


\section{Do Lenders Still Monitor? \\ Leveraged Lending and the Search for Covenants}

presale moral hazard and adverse selection. ${ }^{84}$ Tighter covenants set quick triggers for intervention, so that even a lender expecting to sell its loan would be prompted to investigate earlier and more often than with loose covenants, if for no other reason than to approve a waiver of any violation. Tighter covenants also helped mitigate a loan purchaser's informational disadvantage by offering the same quick trigger for intervention that the seller enjoyed. 85

Overall, the evidence suggests that while syndication and secondary loan trading might theoretically have dampened banks' monitoring incentives, lead banks and selling banks anticipated and addressed this concern for the benefit of syndicate members and loan purchasers, respectively. Lead banks understood their reputational stakes in refraining from opportunism in a syndication. Both lead banks and selling banks took steps to bond themselves as monitors. ${ }^{86}$

\section{B. Demand for Leveraged Loans}

In this section, I describe the evolution from traditional lending to a new and riskier loan market, driven in part by banking deregulation, in part by the advent of junk bonds and the 1980s leveraged buyout boom, in part by modernized bank capital rules, and in part by the advent of securitization. I also discuss the misgivings of regulators and other debt market observers concerned with the new loan market's appetite for risk.

\section{Banking Deregulation and Financial Firms' Consolidation}

Banking deregulation had important effects on lenders and lending markets. Beginning in the late 1970s, bank loan markets changed dramatically, and new forms of bank lending emerged, as states deregulated intrastate branching and interstate banking. ${ }^{87}$ Before deregulation,

\footnotetext{
84 Moreover, tighter covenants help increase borrowers' debt capacity by making their loans more saleable in secondary markets. Id.

85 More generally, bank monitoring continues to have value in the presence of bank debt trading. Amar Gande and Anthony Saunders find that bank loan announcements are associated with positive stock price reactions, even when the borrower's loans already trade on the secondary market. See Amar Gande \& Anthony Saunders, Are Banks Still Special When There Is a Secondary Market for Loans?, 67 J. FIN. 1649 (2012). This result holds even for distressed firms, for which reduced incentives for bank monitoring would ex ante be expected to have the most adverse effects. Id. Additionally, the inception of trading in the borrower's bank debt also elicits a positive stock price reaction, suggesting that bank monitoring and the secondary market offer complementary sources of information about borrower firms. Id.

86 Charles Whitehead has offered a reason to embrace loan markets as a facilitator of lender governance. More complete credit markets may improve governance through transparent pricing of credit risk. In the same way that stock prices inform equity holders about the firm's condition and prospects, liquid credit markets may offer price signals to creditors about a firm's creditworthiness, enabling those creditors to adjust their relations with the firm. Creditors might come to rely on these credit market price signals as a supplement to or substitute for traditional covenants and monitoring. Charles K. Whitehead, The Evolution of Debt: Covenants, the Credit Market, and Corporate Governance, 34 J. CORP L. 641, 660 (2009).

${ }^{87}$ Anthony J. Crawford et al., Bank CEO Pay-Performance Relations and the Effects of Deregulation, $68 \mathrm{~J}$. Bus. 231, 233 (1995) (noting that most states required reciprocity); see R. Glenn Hubbard \& Darius Palia, Executive Pay and Performance: Evidence from the U.S. Banking Industry, 39 J. FIN. ECON. 105, 109 (1995) (describing state-level deregulation of interstate banking beginning in the early 1980s).
} 


\section{Do Lenders Still Monitor? \\ Leveraged Lending and the Search for Covenants}

commercial banking was a relatively clubby, cozy business, with banks operating in fairly protected, geographically segmented markets. ${ }^{88}$ Not only was interstate banking prohibited, ${ }^{89}$ but most states limited the size and geographical scope of banks operating within their borders. ${ }^{90}$ These constraints effectively limited the territorial scope of competition, carving up banking markets within each state. At the start of banking deregulation, only twelve states allowed unrestricted branching. ${ }^{91}$ However, by 1990 , thirtyeight states and the District of Columbia had removed all intrastate branching restrictions. ${ }^{92}$

Interstate banking received a boost at the federal level in 1982: an amendment to the Bank Holding Company Act $^{93}$ sanctioned interstate acquisition of failed banks and thrifts regardless of state law. ${ }^{94}$ Many states responded to the Act by entering into reciprocal multistate agreements freely allowing bank acquisitions among participant states. By 1989, forty-four states and the District of Columbia allowed some interstate banking. ${ }^{95}$ Continuing this trend, the Riegle-Neal Act (RNA) formally unleashed interstate banking across all states in 1994. ${ }^{96}$ Then in 1999, the GrammLeach-Bliley Financial Services Modernization Act (GLB Act) formally repealed the Depression-era barriers among banking, insurance, and securities activities. ${ }^{97}$ This allowed for the formation of multiline financial

\footnotetext{
${ }^{88}$ See generally Crawford et al., supra note 87 (investigating bank CEO compensation from 1976 to 1988); Vicente Cunat \& Maria Guadalupe, Executive Compensation and Competition in the Banking and Financial Sectors, 33 J. BANKING \& FIN. 495, 496 (2009) (testing effects of banking deregulation from 1992 to 2002).

${ }^{89}$ Interstate banking enables a bank holding company (BHC) to own and operate banks in more than one state. Under the Douglas Amendment to the Bank Holding Company Act of 1956, states enjoyed the power to block interstate banking - barring a BHC from acquiring a bank outside its home state without the approval of the target bank's state. 12 U.S.C. $\S 1842$ (d) (2006).

${ }^{90}$ Kevin J. Stiroh \& Philip E. Strahan, Competitive Dynamics of Deregulation: Evidence from U.S. Banking, 35 J. MONEY, CREDIT \& BANKING 801, 806 (2003). In "unit" banking states, branching was strictly prohibited. In effect, each bank was permitted only one place of business - its unit bank-within the state. Other states allowed only limited branching. Id.

91 Id.

92 Id. at 808 tbl.1.

9312 U.S.C. $§ 1842$.

94 Garn-St. Germain Depository Institutions Act (Garn-St. Germain Act) of 1982, Pub. L. No. 97-320, $\S 116,96$ Stat. 1469, 1476-79 (codified at 12 U.S.C. § 1823); see also Randall S. Kroszner \& Philip E. Strahan, What Drives Deregulation? Economics and Politics of the Relaxation of Bank Branching Restrictions, 114 Q.J. ECON. 1437, 1442 (1999) (describing the impact of the Garn-St. Germain Act). The range of permissible products that depository institutions could offer was broadened beginning in 1980. For example, DIDMCA preempted state usury laws capping mortgage interest rates, finance charges, and discount points. DIDMCA, Pub. L. No. 96-221, § 501, 94 Stat. 161, 161-63 (codified at 12 U.S.C. § 1735f7a). The Garn-St. Germain Act authorized depository institutions to offer money market deposit accounts. Garn-St. Germain Act $\S 327$ (codified at 12 U.S.C. § 3503) (directing the Deposit Institutions Deregulation Committee to promulgate rules allowing depository institutions to offer a new deposit account "directly equivalent to and competitive with money market mutual finds"). The Garn-St. Germain Act also preempted state law restrictions on due-on-sale clauses. Garn-St. Germain Act $\S 341$ (codified at 12 U.S.C. $\S 1701$ j$3(\mathrm{~b})(1))$.

95 Stiroh \& Strahan, supra note 90, at 808 tbl.1.

${ }^{96}$ Riegle-Neal Interstate Banking and Branching Efficiency Act of 1994, Pub. L. No. 103-328, 108 Stat. 2338 (codified in scattered sections of 12 U.S.C.).

97 Gramm-Leach-Bliley Act, Pub. L. No. 106-102, § 101, 113 Stat. 1338, 1341 (1999).
} 


\section{Do Lenders Still Monitor? \\ Leveraged Lending and the Search for Covenants}

services firms in the form of bank holding companies. ${ }^{98}$ These important deregulatory statutes pushed commercial banks further out of their cozy protected markets, ${ }^{99}$ forcing them not only to compete with one another across state lines, ${ }^{100}$ but also to compete with investment banks and other diversified financial firms with insurance, securities, and mutual fund businesses. Deregulation initially had salutary procompetitive effects. Increased competition led to greater growth opportunities in commercial banking. ${ }^{101}$ At the same time, banks' traditional financial intermediation business model came under stress. Funding became more problematic, as consumers discovered money market funds and other alternatives to bank deposits. On the lending side, as well, commercial banks faced new competition as investment banks began to offer debt financing in nontraditional forms - short-term commercial paper, for example. ${ }^{102}$

The convergence of activities among banks and securities firms also spurred the largest financial firms to grow larger. Deregulation drove extensive consolidation among investment and commercial banks. "The most striking fact about the industry . . . is the amount of consolidation that has taken place." "103 Between 1979 and 1994, the total number of banking organizations dropped by $36.4 \%$, while gross total assets increased by $23.4 \%$ in real terms. ${ }^{104} \mathrm{~A}$ "top-ten" group of global securities underwriters remained virtually unchanged from 2001-07, ${ }^{105}$ and those ten firms together took in nearly $60 \%$ of global proceeds from securities underwriting for 2005-07. ${ }^{106}$ The "big three" U.S. banks - JP Morgan Chase, Bank of America, and Citigroup - controlled about $60 \%$ of the U.S. syndicated lending market from 2000-07. Around the same time, the "big four" U.S. securities firms-

${ }^{98}$ Id. Before the GLB Act, BHC structures were permitted through the regulatory discretion of federal banking regulators. Jonathan R. Macey, The Business of Banking: Before and After Gramm-Leach-Bliley, 25 J. CORP. L. 691, 692 (2000). Perhaps the most significant effect of the GLB Act was to allow investment banks to acquire commercial banks. $I d$. at 694 . Commercial banks were already being allowed by regulators to acquire investment banking operations by the time of the GLB Act's passage. Id.

99 See Cuñat \& Guadalupe, supra note 88 , at 497.

100 On the heels of the RNA, the total number of bank branches per capita in the United States increased, as did the average number of banks operating at the state level and the average number of states in which a bank operated. See Astrid A. Dick, Nationwide Branching and Its Impact on Market Structure, Quality, and Bank Performance, 79 J. BuS. 567, 585 (2006).

101 The costs and pricing of banking services fell. See Jith Jayaratne \& Philip E. Strahan, Entry Restrictions, Industry Evolution, and Dynamic Efficiency: Evidence from Commercial Banking, 41 J.L. \& ECON. 239, 249-53 (1998). States that dismantled intrastate branching restrictions saw faster growth after deregulation. See Jith Jayaratne \& Philip E. Strahan, The Finance-Growth Nexus: Evidence from Bank Branch Deregulation, 111 Q.J. ECON. 639, 639 (1996). Interstate competition also led to reallocation of assets to more efficient banks. See Stiroh \& Strahan, supra note 90, at 804.

${ }^{102}$ Elisabeth de Fontenay, Do the Securities Laws Matter? The Rise of the Leveraged Loan Market, 39 J. CORP. L. 725, 739 (2014).

${ }^{103}$ Berger Kashyap Scalise, The Transformation of the U.S. Banking Industry: What a Long, Strange Trip It's Been, 2 BROOKINGS PAPERS ON ECONOMIC ACTIVITY 55, 66 (1995).

${ }^{104} I d$. at $66-67 \&$ tbl. 1.

${ }^{105}$ Arthur E. Wilmarth, Jr., The Dark Side of Universal Banking: Financial Conglomerates and the Origins of the Subprime Financial Crisis, 41 CONN. L. REv. 963, 980 (2009). This group was comprised of the "big three" U.S. banks - Citigroup, JP Morgan Chase, and Bank of America - three major foreign banks - Credit Suisse, Deutsche Bank, and UBS - and the "big four" U.S. securities firms - Merrill Lynch, Morgan Stanley, Goldman Sachs, and Lehman Brothers. Id.

${ }^{106}$ Id. at 981 . 


\section{Do Lenders Still Monitor? \\ Leveraged Lending and the Search for Covenants}

Merrill Lynch, Morgan Stanley, Goldman Sachs, and Lehman Brothersbecame active players in the leveraged loan market. That market saw rapid growth in response to investors' demands for higher-yielding investments and private equity firms' need for leveraged buyout financing. ${ }^{107}$ Global leveraged lending grew from $\$ 250$ billion in 1996 to $\$ 1.6$ trillion in $2007 .{ }^{108}$ This explosion of leveraged lending fueled a global LBO boom. ${ }^{109}$

\section{Junk Bonds and Leveraged Buyouts}

Up through the 1970s, public firms' balance sheets were quite conservative. New public bond issues were typically investment grade, implying very low default risk, but also offering financing only for the most creditworthy firms. During this period, bank lending was also fairly straightforward, as described above. Banks generally held their loans to maturity; selling loans was rare. Relationship banking was the norm, and banks' private information gleaned from monitoring their borrowers was an important asset, giving each bank some competitive edge with respect to its familiar borrowers. ${ }^{110}$ This was the traditional "originate-to-hold" model of syndicated lending, as compared to the more recent "originate-to-distribute" model we discuss below. ${ }^{111}$

The advent of junk bonds and the leveraged buyout boom of the 1980s taught companies to get comfortable with riskier capital structures. ${ }^{112}$ Rather than simply husbanding debt for operational needs, firms could tap burgeoning debt markets for acquisition purposes. Private equity firms regularized the practice of borrowing large sums to take firms private, typically using a mix of bank loans and junk bonds, thereby increasing demand for both. This demand in turn led to more and more syndicated lending, which enabled banks to diversify risk by sharing the funding of large corporate loans. ${ }^{113}$

\footnotetext{
${ }^{107} I d$. at $982-83$.

${ }^{108}$ Comm. on the Global Fin. System, Private Equity and Leveraged Finance Markets 11 graph 2.2, 17-21 (CGFS Papers, Working Paper No. 30, 2008), available at www.bis.org/publ/cgfs30.htm. By 2004, global leveraged lending was at $\$ 700$ billion; it hit $\$ 900$ billion in 2005 and $\$ 1.2$ trillion in 2006. Id.

${ }^{109}$ Viral V. Acharya et al., Private Equity: Boom and Bust?, 19 J. ApPLIED CORP. Fin., Fall 2007, at 44-46, 49-50; Edward I. Altman, Global Debt Markets in 2007: New Paradigm or the Great Credit Bubble?, 19 J. APPLIED CORP. FIN., Summer 2007, at 17, 24-25. More than half the leveraged loans issued in the U.S. and Europe from 2004-07 were used to finance LBOs and other corporate transactions. Comm. on the Global Fin. System, supra note 108, 14 graph 2.6.

110 E.g., Sreedhar T. Bharath, Sandeep Dahiya, Anthony Saunders, and Anand Srinivasan, Lending Relationships and Loan Contract Terms, 24 REV. FIN. STUD. 1141, 1141-42 (2011) (showing that reduced information asymmetry leads to lower loan spreads, especially for opaque borrowers).

${ }^{111}$ Simons, supra note 64, at 45-46; de Fontenay, supra note 102, at 739.

${ }^{112}$ So-called "junk bonds," also referred to as high-yield debt, are riskier than investment grade bonds. Bonds with a Standard \& Poor's rating below BBB- or a Moody's rating below Baa3 are generally considered below investment grade. S\&P GLOBAL, A SYNDICATED LOAN PRIMER 9 (April 2016); available at https://www.lcdcomps.com/d/pdf/2016\%20US\%20Loan\%20Primer.pdf. A leveraged buyout is a merger transaction in which a private equity firm pays for control of the target using primarily borrowed funds, much of which is collateralized by the target's assets. [cite]

${ }^{113}$ Bridget Marsh \& Tess Virmani, Loan Syndications and Trading: An Overview of the Syndicated Loan Market, in LENDING \& SECURED FINANCE 2 (2020), available at https://iclg.com/practice-areas/lending-andsecured-finance-laws-and-regulations/01-loan-syndications-and-trading-an-overview-of-the-syndicatedloan-market.
} 


\section{Do Lenders Still Monitor? \\ Leveraged Lending and the Search for Covenants}

One consequence of the greater comfort with more highly leveraged capital structures has been the expansion of leveraged lending — bank lending to below-investment-grade firms. Because leveraged loans face higher default risk than investment grade loans, borrowers face steeper pricing for both loan spreads and arranger fees. The prospective high returns to lenders attracted significant investor interest beginning in the mid-1990s, as nonbank financial institutions ("institutional lenders," also sometimes called "shadow banks") jumped into the leveraged loan market. ${ }^{114}$ CLOs, mutual funds, pension funds, and insurance companies have been the most active institutional lenders in the leveraged loan market. ${ }^{115}$

\section{Modernizing Bank Capital}

Modernized bank capital rules helped to shape the emergence and contours of the leveraged loan market. Beginning in the 1970s, central bankers in ten economically advanced countries began to meet regularly to craft and coordinate improvements to the quality of banking supervision worldwide. This group became the Basel Committee, ${ }^{116}$ which over the past decades has established international standards and practices for banking regulation. Among other things, the Basel Committee introduced and refined bank capital rules. Bank capital acts as a buffer against losses, analogous to corporate equity, and banking regulations specify minimum capital requirements for banks to operate. The minimum capital requirements are expressed as a ratio of capital to assets. During the 1980s, the Basel Committee introduced risk weighting for assets. Different types of assets implicate different types and levels of risk, so the Basel risk-weighted assets (RWA) approach assigns bank assets to various risk categories, with riskier categories requiring more capital. For example, under Basel I, commercial loans were weighted at $100 \%$; residential mortgages were weighted at only $50 \%$; and sovereign debt incurred a $0 \%$ weighting - that is, sovereign debt required no corresponding capital buffer. Over time, the Basel Committee set three important minimum capital-to-RWA ratios: one for "core" or "tier 1" capital; a similar ratio for total capital, which includes tier 1 capital plus

\footnotetext{
${ }^{114}$ Allison A. Taylor \& Ruth Yang, Evoluation of the Primary and Secondary Leveraged Loan Markets, in THE HANDBOOK OF LOAN SYNDICATIONS AND TRADING 24 (2007) ("These nonbank buyers increased demand for leveraged loan products, thereby enabling the larger agent banks to underwrite and distribute increasingly bigger loans.") (hereinafter HANDBOOK OF LOAN SYNDICATIONS).

115 Jerome H. Powell, Business Debt and Our Dynamic Financial System, Remarks by Jerome H. Powell, Chair, Board of Governors of the Federal Reserve System 4 \& fig. 4 (May 20, 2019).

116 The Committee has since expanded to include 45 institutions from 28 jurisdictions. BANK OF INTERNATIONAL SETTLEMENTS, HistORY OF THE BASEL COMMITTEE, available at https://www.bis.org/bcbs/history.htm.
} 


\section{Do Lenders Still Monitor? \\ Leveraged Lending and the Search for Covenants}

additional items, ${ }^{117}$ and a "common equity tier 1 " or "CET1" ratio, which uses a definition of capital narrower than tier $1 .{ }^{118}$

Consistent with the modern portfolio theory behind these risk-based capital rules, banks were pushed to diversify their loan portfolios. ${ }^{119}$ The new capital rules deterred banks from holding just a relative handful of large loans confined to a particular region or locality. Instead, banks were incentivized to hold larger passels of smaller loans that were geographically more balanced. ${ }^{120}$ More generally, by the early 2000 s, with portfolio management being the order of the day, a bank could no longer simply originate loans based on a one-time risk assessment and hold the loans to maturity. Instead, portfolio rebalancing meant some amount of loan selling. So rather than continuing with a straight originate-to-hold approach to lending, banks began to pare their portfolios to reduce regulatory capital costs. One 2002 survey of 41 prominent banks explored their experience with the nascent practice of portfolio management. The survey showed that $73 \%$ of respondents had transferred a loan to a CLO, and that "regulatory capital" concerns were the most important motivation. ${ }^{121}$ Asked to rank four tools for loan portfolio management, respondents ranked "loan sales and trading" as the second most important tool, after "approval/ disapproval of new business and renewals/ nonrenewal of existing business." 122 With new technology to measure risk and diversification, banks learned to optimize their portfolios and enhance their returns with the judicious selling of loans. ${ }^{123}$

A secondary loan market thus emerged, with originate-to-distribute lending and plenty of non-bank lenders to populate that market.

\footnotetext{
${ }^{117}$ Tier 1 includes common stockholders' equity, noncumulative perpetual preferred stock, minority interests in consolidated subsidiaries, and some other items. Total capital incorporates tier 2 capital, which includes allowances for loan losses, cumulative preferred stock, long-term preferred stock, and some subordinated debt. Tier 2 capital also cannot exceed tier 1 capital. Joseph G. Haubrich, A Brief History of Bank Capital Requirements in the United States, ECONOMIC COMMENTARY 4 \& 6 n.6 (FRB Cleveland) No. 2020-05 (Feb. $28,2020)$.

${ }^{118}$ Id. at 4. Basel III and the Dodd-Frank Act also created "capital buffers" for the large banks. A capital conservation buffer (CCB) precludes large banks from making capital distributions if their capital is less than $2.5 \%$ above the minimum ratio. Global systematically important banks (GSIBs) face a special surcharge meant to offset systemic risk. GSIBs are also required to meet a total loss absorbing capacity (TLAC) threshold, which is a minimum ratio of equity plus long-term debt. The requirement for a countercyclical capital buffer $(\mathrm{CCyB})$ is meant to raise banks' capital requirements during an economic expansion, essentially to moderate a potentially overheating economy. $I d$. at 5 .

${ }^{119}$ E.g., Basel Committee on Banking Supervision, International Convergence of Capital Measurement and Capital Standards: A Revised Framework, Comprehensive Version, BANK FOR INTERNATIONAL SETTLEMENTS (June 2006), available at https://www.fsb.org/2006/06/cos 060601/. See also de Fontenay, supra note 102 , at $739-41$.

${ }^{120}$ Whitehead, supra note 86, at 654-65 (noting that "new regulatory capital requirements made it more expensive for banks to continue the lending business as they had before," and "many [banks] turn[ed] to a defensive, portfolio-based strategy in order to minimize their overall credit cost.").

${ }^{121}$ Charles Smithson, Stuart Brannan, David Mengle \& Mark Zmiewski, Results from the 2002 Survey of Credit Portfolio Management Practices 5 (2002); available at https://studylib.net/doc/8175108/2002-surveyof-credit-portfolio-management-practices. Most of the institutions (81\%) were commercial banks headquartered in North America or Europe. Id. at 2.

${ }^{122} I d$. The mean rank for "loan sales and trading" was 2.74 . The mean rank for "approval/ disapproval of new business" was 1.10. Id.

${ }^{123}$ Whitehead, supra note 86 , at $655-56$ \& n.103 (noting the development of credit portfolio modeling and new methods for measuring loan portfolios' risk and return characteristics).
} 


\section{Do Lenders Still Monitor? \\ Leveraged Lending and the Search for Covenants}

\section{Securitization: Collateralized Loan Obligations}

CLOs deserve special mention. Sixty-some percent of outstanding leveraged loans are securitized: ${ }^{124}$ the loan is sold to a special purpose vehicle (SPV), which succeeds to the loan's cash flow and control rights. The SPV buys many loans, or slices of syndicated loans, and then issues securities"collateralized loan obligations," or CLOs - to investors, backed by the cash flows of the loans in the SPV. ${ }^{125}$ The CLO securities are tranched, such that the senior-most securities are the safest and most highly rated. More junior tranches enjoy a higher interest rate for having to shoulder greater risk. The lowest tranches typically suffer the first losses in the collateral pool. Securitization is an ever-expanding tool of modern finance, in both its sheer dollar volume and the steadily growing variety of its sources of cash flows.

CLOs have become the major holders of leveraged loans. A conventional wisdom suggests that CLO loans face not only weak covenants but also anemic monitoring, though existing evidence appears mixed. ${ }^{126}$ For present purposes, we note CLO securitization as an important driver of the leveraged loan market.

\section{C. $\quad$ The Shape of Leveraged Lending}

With the metamorphosis to syndicated originate-to-distribute lending and loan trading, it was a short step to creating different types of loans for different types of lenders for the leveraged loan market. While banks still typically act as arrangers, they traditionally prefer to hold what is known as "pro rata" debt, a package that includes a revolving loan with traditional financial covenants, ${ }^{127}$ and an amortizing term loan (typically referred to as

\footnotetext{
${ }^{124}$ Powell, supra note 115 , at 4 (noting that $62 \%$ of then-outstanding leveraged loans were held by CLOs). Mutual funds, the next largest holders of leveraged loans, own about $20 \%$ of the market. Id.

125 "CLO" is generally used to refer to not only the loan-backed bonds but also the entire structured finance transaction or entity. A typical CLO may include over a hundred different loans, with the average loan size ranging from $\$ 2$ million to $\$ 3$ million. Efraim Benmelech, Jennifer Dlugosz \& Victoria Ivashina, Securitization without Adverse Selection, 106 J. FIN. ECON. 91, 94 (2012). In 2015, the average CLO held $\$ 500$ million to $\$ 600$ million in principal amount of loans spread over an average of 140 borrowers. Stavros Peristani \& João A.C. Santos, Investigating the Trading Activity of CLO Portfolio Managers, LIBERTY $\begin{array}{lllll}\text { STREET ECON. } & \text { (Aug. } & 3, & 2015) ; & \text { available }\end{array}$ https://ibertystreeteconomics.newyorkfed.org/2015/08/investigating-the-trading-activity-of-clo-portfoliomanagers.html.

${ }^{126}$ Compare Yihui Wang \& Han Xia, Do Lenders Still Monitor When They Can Securitize Loans?, 27 REV. FIN. STUD. 2354 (2014); Vitaly M. Board \& João A.C. Santos, Does Securitization of Corporate Loans Lead to Riskier Lending?, 47 J. MONEY, CREDIT \& BANKING 415 (2015) (finding that securitized leveraged loans perform worse than non-securitized loans); with Berlin, Nini \& Yu, supra note 127; Benmelech, et al., supra note 125 (finding no consistent evidence that securitized leveraged loans performed worse than unsecuritized loans).

${ }^{127}$ Mitchell Berlin, Greg Nini \& Edison G. Yu, Concentration of Control Rights in Leveraged Loan Syndicates, 137 J. FIN. ECON. 249, 250 (2020) (noting that the line of credit in a leveraged loan deal nearly always contains traditional financial covenants, even if no term loan does). A revolving loan is an unfunded loan that allows the borrower repeatedly to draw and then repay funds as the borrower wishes during the life of the loan, up to a specified aggregate limit, much like a credit card. Interest is charged only for the periods and amounts that funds are outstanding. Banks typically originate and manage revolving loans. An amortizing term loan typically requires regular periodic payments of the same amount over the life of the loan, with each payment consisting of two components: (a) an amount that pays off the accrued interest from the preceding
} 


\section{Do Lenders Still Monitor? \\ Leveraged Lending and the Search for Covenants}

the TLA). ${ }^{128}$ The package is pro rata insofar as each lender in the syndication commits to a share of the revolver equal to its share of the TLA. ${ }^{129}$ Institutional lenders, by contrast, prefer riskier loans, typically nonamortizing term loans, called TLBs. The "B" refers to the "bullet" nature of the loan. Maturity is typically longer than for the TLA loan, and in the absence of amortization, the borrower makes only regular periodic interest payments over the life of the loan. The entire principal amount (the "bullet") is due at maturity. ${ }^{130}$ Institutional lenders fund the lion's share of leveraged loans. ${ }^{131}$ Loan credit ratings and secondary market trading standards have greatly facilitated institutional trading. ${ }^{132}$

Institutional lenders can take on these riskier loans because they are free of the capital requirements and stringent regulation applied to commercial banks. This regulatory differential has led to a symbiotic arbitrage, where banks arrange risky loans that they are not willing to hold on their own books, but instead sell to institutional lenders. ${ }^{133}$ This approach has facilitated the "originate-to-distribute" model of loan syndication. While continuing their traditional relationship lending, banks also create institutional tranches for the shadow banks in the form of riskier TLBs. Like the revolving loans, leveraged term loans are typically secured by first priority liens on collateral, sharing equal priority with the revolving loan. As syndicated lending has become more specialized, it has also become common

period; and (b) an amount for reduction of principal. Over the life of the loan, the interest component decreases monotonically while the principal component does just the opposite, such that the final payment retires the remaining principal amount, as well as the remaining small sliver of interest due. [cite]

${ }^{128}$ An amortizing loan is a loan with a repayment schedule of equal periodic payments over the life of the loan. Each periodic payment includes some repayment of principal, as well as interest on the remaining principal amount. Payments early on the life of the loan are comprised primarily of interest, with just a small principal repayment component. With each succeeding payment, the interest component decreases - because the unpaid principal amount decreases with each payment-while the principal repayment component increases. The very last payment, which retires the loan, is comprised almost entirely of principal, with just a sliver of interest. See Julia Kagan, Amortized Loan, INVESTOPEDIA (updated Oct. 30, 2020), available at https://www.investopedia.com/terms/a/amortized loan.asp.

129 S\&P Global, LeVeraged COMMENTARY \& DATA (LCD): LEVERAGEd LOAN Primer 8 (2020); available at https://www.spglobal.com/marketintelligence/en/documents/lcd-primer-leveragedloans 1tr updated.pdf. By the late 2000s, amortizing term loans became less common, as institutional lenders preferred the revolver/ institutional term loan (i.e., non-amortizing) arrangement. Id. at 6.

${ }^{130} \mathrm{Id}$. at 6; HANDBOOK OF LOAN SYNDICATIONS, supra note 114, at 717. This "bullet" feature is not necessarily as draconian as it may sound. Corporate borrowers will typically honor their repayment commitment by refinancing - taking out a new loan to repay the maturing loan. When multiple institutional term loan tranches are created at the same time, they are typically named in alphabetical order, which coincides with maturity order. For example, the TLB may mature in six years, the TLC in seven years, and so on. Id.

${ }^{131}$ Banks held less than $8 \%$ of leveraged loans as of the end of 2018. Powell, supra note 115 , at $5 \&$ fig. 4 .

${ }^{132}$ In 2007, institutional lenders funded $62 \%$ of primary leveraged loan issuance. Victoria Ivashina \& Zheng Sun, Institutional Demand Pressure and the Cost of Corporate Loans, 99 J. FIN. ECON. 500, 501(2011).

${ }^{133}$ Moreover,

There is only so much safety and soundness regulators can do about this, for much of the market is populated by nonbank lenders and nonbank purchasers and so lies outside of their immediate reach ... $[R]$ egulatory initiatives against the banks are thought to have played a causative role in the nonbank surge.

Bratton \& Levitin, supra note 16, at 104. See also Andrew Berlin, Regulated Banks Soften Stance on Leveraged Lending Guidance, REUTERS (Apr. 19, 2018) (explaining the regulatory easing by the Fed and OCC enabling debt packages with leverage of up to 7.75 times in 2018 , as compared to the six-times leverage cap in 2013). 
that banks hold only revolvers, leaving the borrower's term loans to the shadow banks. ${ }^{134}$

With debt investors continually on the hunt for higher yields, the US leveraged loan market has exploded since the financial crisis, more than doubling in size, ${ }^{135}$ as Figure 1 shows below. By the end of 2019, the leveraged loan market was worth $\$ 1.2$ trillion, with institutional lenders holding $90 \%$ of that market. ${ }^{136}$ At the same time, on the borrower's side, $70 \%$ of US companies are rated below investment grade, ${ }^{137}$ including household names like Wendy's, Hertz, Hilton Worldwide Holdings, Jaguar, and United Airlines.

\section{Figure 1: GROWTH IN LEVERAGED \& COV-LITE LOANS $2000-2019$ (JULY)}

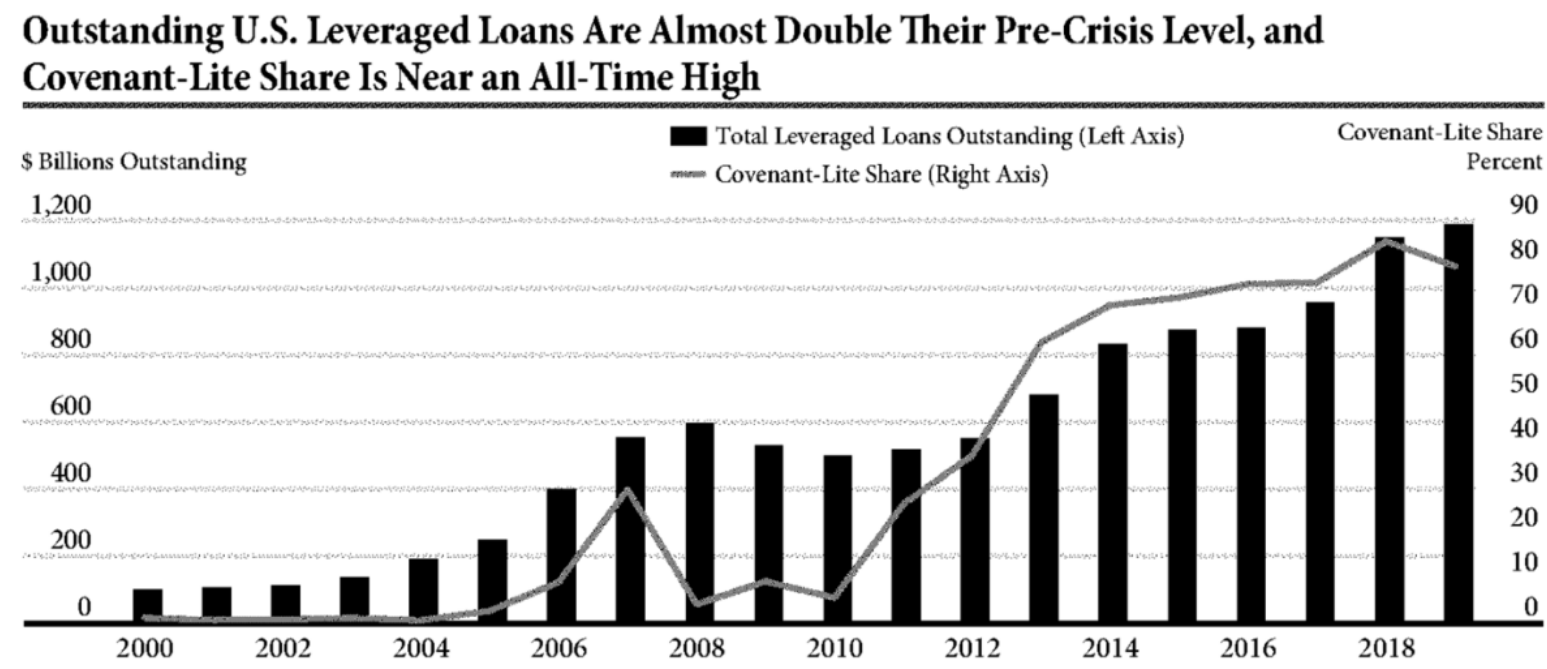

Source: S\&P Leveraged Commentary and Data.

Notes: Outstanding loan data cover loans included in the S\&P/Loan Syndications and Trading Association Leveraged Loan Index and thus underestimate the full market. Covenant-lite share is of institutional leveraged loan issuance. Data are through July 2019.

\section{Fear of Flying: Regulators' View}

Debt markets have become far more comfortable with riskier loans than in previous years. Regulators, rating agencies, and other debt market observers worry that market demand for leveraged loans has enabled

\footnotetext{
${ }^{134}$ Edison Yu, Banking Trends: Measuring Cov-Lite Right, FED. RES. BANK OF PHILADELPHIA 3 (2018).

${ }^{135}$ From the end of 2008 to Q1 2019, outstanding institutional leveraged loans grew by $101 \%$. Frank MartinBuck, Leveraged Lending and Corporate Borrowing: Increased Reliance on Capital Markets, with Important Bank Links, 13 FDIC Q. 41, 43 (2019).

${ }^{136}$ Sierra, supra note 8 . In the mid-1990s, banks funded more than $70 \%$ of institutional leveraged loans. Martin-Buck, supra note 135, at 45.

${ }^{137}$ SIFMA, LEVERAGE LENDING FAQ \& FACT SHEET 2 (2019); available at https://www.sifma.org/wpcontent/uploads/2019/03/Leverage-Lending-FAQ.pdf.
} 


\section{Do Lenders Still Monitor? \\ Leveraged Lending and the Search for Covenants}

borrowers to cut deals with increasingly weaker covenants. ${ }^{138}$ Historically, leveraged loans typically included financial maintenance covenants. The borrower committed to maintaining a certain ratio of debt to cash flow, for example, or a cap on total debt. Virtually all leveraged loans included maintenance covenants in the early 2000s. ${ }^{139}$ By 2007, 29\% of new loansso-called "covenant-lite" or "cov-lite" loans-omitted these covenants. Instead, loans might include "incurrence" covenants, which require compliance with caps or ratios only when the borrower pursues a specified significant action like issuing new debt or dividends, or making an acquisition. While the proportion of cov-lite loans fell in the aftermath of the financial crisis, cov-lite roared back through 2018 to comprise $85 \%$ of new loans. ${ }^{140}$

In addition to weakened covenants and the associated corporate governance implications, other risk-enhancing practices have emerged as well in recent years. Not only has reported leverage increased, but the growing practice of earnings "add-backs" suggests that actual leverage may be even more worrisome. With acquisitions, private equity buyouts, and other extraordinary transactions, sponsors and targets naturally expect to show synergies or operational improvements that justify valuations exceeding the costs of the deal. With the understandable aim of presenting a fair picture of the borrower's future earnings following an extraordinary transaction, the borrower often adds back non-recurring items that affect cash flows or accruals. $^{141}$

Lenders in turn will concur with borrowers' upward adjustments to EBITDA to reflect this assumed augmentation of value. Borrowers of course may end up overstating adjusted EBITDA through add-backs, which then understates the target's debt-to-EBITDA ratio, a typical baseline leverage measure. ${ }^{142}$ Add-backs are becoming more and more common. Their magnitudes have raised concerns from regulators. The Financial Stability Board estimates EBITDA adjustments of $15-30 \%$ for incurrence covenants

${ }^{138}$ William W. Bratton, Bond and Loan Covenants, Theory and Practice, 11 CAP. MKTS. L.J. 461, 478-79 (2016). See also Aaron Weinman, Demand for Leveraged Loans Ignites Market, Concerns on Risk, REUTERS (Feb. 5, 2020) ("Investors' pockets are flush with cash looking for a home, and borrowers have leveraged this to either reprice their debt at ultra-low rates or obtain cheap new cash for acquisitions that may have been difficult to execute a year ago.").

${ }^{139}$ Martin-Buck, supra note 135, at 44. One study of public company credit agreements from 1996-2005 found that almost 97 percent included at least one financial covenant. Michael R. Roberts \& Amir Sufi, Control Rights and Capital Structure: An Empirical Investigation, 64 J. FIN. 1657, 1662 (2009).

${ }^{140} I d$.

${ }^{141}$ For example, as part of the spin-off of Engility Holdings, Inc. by L-3 Communications Holdings, Inc. in July, 2012, Engility entered into a $\$ 400$ million credit agreement with Bank of America, as Administrative Agent. Engility's definition of Consolidated EBITDA runs for 520 words, and includes addbacks not only for interest, taxes, depreciation, and amortization. It also adds back certain "non-cash stock-based compensation expenses," certain "cost savings, operating expense reductions and synergies projected by the Borrower in good faith to be realized . ...," certain "extraordinary or non-recurring charges, expenses or losses," and certain "other non-cash charges, expenses or losses." CREDIT AGREEMENT, DATED AS OF JULY 17, 2012, AMONG ENGILITy Holdings, InC., ENGILITY CORPoration, BANK OF AMERICA, N.A., AS Administrative Agent, AND the Lenders From Time to Time PARTY Hereto 7-; available at https://www.sec.gov/Archives/edgar/data/1544229/000119312512309118/d381537dex101.htm.

${ }^{142}$ Financial Stability Board, Vulnerabilities Associated with Leveraged Loans and Collateralised Loan Obligations 9 (2019). 


\section{Do Lenders Still Monitor? \\ Leveraged Lending and the Search for Covenants}

in current deals. ${ }^{143}$ Studies by both Standard \& Poors and Moody's show that firms' rosy EBITDA projections often fall materially short in the two years post-closing. ${ }^{144}$

While Federal Reserve Chair Jerome Powell has expressed confidence that the banking system is "fundamentally stronger and more resilient" than during the financial crisis, he also offers some caution in mid2019:

Business debt has clearly reached a level that should give businesses and investors reason to pause and reflect. ... Many measures confirm that the business sector has significantly increased its borrowing as the economy has expanded over the past decade. Business debt relative to the size of the economy is at historic highs. . . . And investment-grade corporate debt has shifted closer to the edge of speculative grade. ... Among investment-grade bonds, a near-record fraction is at the lowest rating .... [U]nderwriting standards have weakened. With leveraged loans, covenants intended to protect lenders may be an endangered species; more loans now feature high debt-to-earnings ratios; and the use of optimistic projections . . . is becoming more common. ${ }^{145}$

In his 2015 speech on financial stability, then-Fed Board Member Powell made similar remarks about the dearth of covenants, noting that "[p]rice and non-price terms in the syndicated leveraged loan market have been highly favorable to borrowers . . . . The share of loan agreements that lack traditional maintenance covenants increased to historic highs."146

Earlier, in spring of 2013, U.S. bank regulators had issued "Interagency Guidance on Leveraged Lending" (IGLL), offering "sound practices for leveraged finance activities." The Guidance cautioned that financial institutions "should ... not unnecessarily heighten risks by originating poorly underwritten loans," and bemoaned that "debt agreements have frequently included features that provided relatively limited lender protection including

\footnotetext{
${ }^{143} I d$. at 9. "Current deals" covers deals through the end of 2018. Id. at n.31.

${ }^{144}$ S\&P GLOBAL, When the Credit Cycle Turns: The EBITDA Add-Back Fallacy (Sept. 24, 2018), available at https:/www.spglobal.com/en/research-insights/articles/when-the-credit-cycle-turns-the-ebitda-add-backfallacy; S\&P GLOBAL, Comments-When the Cycle Turns: The Continued Attack of the EBITDA Add-Back (Sept. 19, 2019), available at https://www.spglobal.com/ratings/en/research/articles/190919-when-thecycle-turns-the-continued-attack-of-the-ebitda-add-back-11156255; MoODY's, Research: Announcement: EMEA Spec-Grade Firms Are Making Higher Earnings Adjustments to Attract Investors (June 27, 2018), available at https://www.moodys.com/research/Moodys-EMEA-spec-grade-firms-are-making-higherearnings-adjustments--PR_385895.

${ }^{145}$ Powell, supra note 115, at 2-4. At the same time, Chairman Powell noted that capital levels and liquidity are much higher at bank holding companies than before the financial crisis, and more generally that the financial system is better prepared for an economic downturn, should it arise. Id. at 8, 11 .

${ }^{146}$ Jerome H. Powell, Financial Institutions, Financial Markets, and Financial Stability, Remarks by Jerome H. Powell, Member, Board of Governors of the Federal Reserve System 11 \& fig. 9 \& 10 (Feb. 18, 2015).
} 


\section{Do Lenders Still Monitor? \\ Leveraged Lending and the Search for Covenants}

... the absence of meaningful maintenance covenants in loan agreements" and "the participation of unregulated investors." 147

The Kansas City Fed has also recently raised concerns with the growing absence of covenant protections:

[M] any observers' concerns stem from reduced credit enhancement protections on syndicated loans. Covenants and other borrower protections have declined during the post-crisis period, likely leaving lenders with less monitoring authority and fewer recourse channels should borrowers default on their loans. . . . Declining borrower protections could also lead to lower recovery rates than in the past if firms were to default. ${ }^{148}$

\section{THE NEW LENDER GOVERNANCE}

The rise in leveraged and cov-lite loans, and the increasing packaging of these loans into CLOs, has created concerns about systemic risk and the future of lender governance. Law and finance scholars worry that the beneficent effects of lender governance may fall by the wayside as the explosive demand for leveraged loans seems to lead to weakened covenants and enforcement. The larger and more diverse institutional syndicates associated with leveraged loans may create greater holdout opportunities and renegotiation frictions. Going cov-lite tends to avoid these holdout problems, thereby potentially streamlining the resolution of conflict among syndicate members and the borrower. ${ }^{149}$ Lender governance could weaken, however.

\footnotetext{
${ }^{147}$ Emphasis supplied. In addition, "the capital structures and repayment prospects for some transactions ... have at times been aggressive," and "management information systems (MIS) at some institutions have proven less than satisfactory in accurately aggregating exposures on a timely basis." Board of Governors of the Federal Reserve System, Federal Deposit Insurance Corporation \& Office of the Comptroller of the Currency, Interagency Guidance on Leveraged Lending 1-2 (March 21, 2013). Studies show that banks generally did not react when IGLL was first issued. Instead, only with the Fed's issuance of a clarifying FAQ on November 7, 2014 did banks respond. Board of Governors of the Federal Reserve System, Federal Deposit Insurance Corporation \& Office of the Comptroller of the Currency, Frequently Asked Questions (FAQ) for Implementing March 201 Interagency Guidance on Leveraged Lending (Nov. 7, 2014). The most heavily supervised banks (subject to oversight by the Large Institution Supervision Coordinating Committee (LISCC) reduced leveraged lending activity significantly, to levels below the pre-IGLL period. Market share for LISCC banks declined by 11 (5) percentage points in number (volume) of leveraged loans from November 2014 - December 2015. Non-LISCC banks did not change their leveraged lending levels in response to the IGLL or the subsequent clarifying FAQ. Nonbanks increased their leveraged lending throughout, taking significant market share away from banks. By number of loans, nonbanks increased market share by over $50 \%$; dollar volume more than doubled. This should not be too surprising, since supervisory guidance directly affects only banks. Post-FAQ, borrowers from a LISCC bank were also more likely to switch to nonbank lenders. Sooji Kim, Matthew C. Plosser \& João A.C. Santos, Macroprudential Policy and the Revolving Door of Risk: Lessons from Leveraged Lending Guidance, 34 J. FIN. INTERMEDIATION 17, 17-18 (2018). Similar results obtain for US and foreign banks versus nonbanks. Paul Calem, Ricardo Correa \& Seung Jung Lee, Prudential Policies and Their Impact on Credit in the United States, 42 J. FIN. INTERMEDIATION 1, 14 \& 15 tbl. 11 (2020). Of course, moving risky lending away from banks and toward nonbanks may not have reduced financial system risk overall.

148 W. Blake Marsh \& Seung Jung Lee, What's Driving Leveraged Loan Spreads, FED. RES. BANK OF KANSAS CitY: THE MACRO BULlETIN 4 (Feb. 27, 2019).

${ }^{149}$ Matthew T. Billett, Redouane Elkamhi, Latchezar Popov \& Raunaq S. Pungaliya, Bank Skin in the Game and Loan Contract Design: Evidence from Covenant-Lite Loans, 51 J. Fin. QUANT. ANALYSIS 839 (2016).
} 


\section{Do Lenders Still Monitor? \\ Leveraged Lending and the Search for Covenants}

Over the past few decades, covenant- and loan structure and strategy have evolved to address the perceived increased risks from excessive leverage and cov-lite lending. Private ordering in loan contracts has emerged to ameliorate regulators' concerns with respect to both the perceived dearth of covenant constraints and the potential excesses of add-backs.

Split control rights enable the application of traditional financial maintenance covenants even to cov-lite loans, which ordinarily contain no such covenants. The traditional covenants are contained in the revolving loan agreement that typically accompanies leveraged and cov-lite term loans in a multi-loan deal. So traditional covenants apply to the borrower, even though not every loan in the deal package may reflect those same covenants. At the same time, only the bank lenders on the revolving loan typically enjoy the right to renegotiate or waive violations of the covenants in the deal. With split control, cov-lite loans do not skirt or weaken covenant constraints. Instead, split control facilitates renegotiation by concentrating control rights with a smaller, more cohesive subset of lenders - the bank lenders on the revolving credit agreement - to discipline the borrower.

Similarly, while add-backs may cause trepidation for regulators, upward adjustments to EBITDA may do more than simply massage borrowers' leverage ratios. New research by Badawi, Dyreng, de Fontenay and Hills (BDDH) suggests that permissive use of add-backs may improve the informativeness of signals to lenders about the borrower's condition. Better information with respect to EBITDA may eliminate noisy features of accounting earnings, such that add-backs may facilitate tighter covenants while also reducing the incidence of false positive violations, thereby avoiding costly renegotiation. ${ }^{150}$ Permissiveness with respect to add-backs correlates with covenant tightness.

More generally, covenants appear to have become more efficient. Cash flow covenants have largely replaced balance sheet covenants in private loan agreements. Cash flow covenants are more discriminating. Financial covenants have also become less restrictive in terms of both the number of covenants in a given loan agreement and their strictness, leading to fewer reported violations, as well as fewer false positives. ${ }^{151}$

\section{A. $\quad$ Split Control}

Simply tracking the presence or absence of covenants in a particular loan may not accurately characterize the covenant constraints at play. In a world of leveraged lending with different types of lending institutions pursuing different loan structures, a loan deal may incorporate multiple loans with non-uniform features, such as varying maturity or covenant structure. ${ }^{152}$

\footnotetext{
${ }^{150}$ Adam B. Badawi, Scott D. Dyreng, Elisabeth de Fontenay \& Robert W. Hills, Contractual Complexity in Debt Agreements: The Case of EBITDA, Working Paper (May 2021); available at https://ssrn.com/abstract=3455497.

${ }^{151}$ See infra Part III.C.

152 S\&P Global, LeVeraged Commentary \& DATA (LCD): LeVERAGed LOAN PRimer 6 (2020); available at $\mathrm{https}: / / \mathrm{www} .1 \mathrm{cdcomps.com} / \mathrm{d} / \mathrm{pdf} / \mathrm{LCD} \% 20 \mathrm{Loan} \% 20$ Primer.pdf.
} 


\section{Do Lenders Still Monitor? \\ Leveraged Lending and the Search for Covenants}

In an important recent study, Berlin, Nini \& Yu (BNY) show that while institutional leveraged loans and cov-lite loans have proliferated in recent years, very few loan deals-which involve contemporaneous or nearcontemporaneous origination of multiple loans to a single borrower-are issued without traditional maintenance covenants. ${ }^{153}$ Banks are partial to revolving loans, which typically include financial maintenance covenants. In many of the deals, the institutional term loans include identical covenants. But whether they do or not, only the banks, and not the institutional lenders, enjoy the right to renegotiate the covenants or waive violations. ${ }^{154} \mathrm{BNY}$ call this "split control," which allows a subset of lenders - the revolver lenders, typically - to discipline the borrower firm. Other lenders in the dealtypically, the institutional lenders-have no say in the renegotiation. This split control is meant to concentrate control rights with a smaller group of lenders. This pared-down set of bank lenders offers a tighter and more cohesive workout group to negotiate with the borrower firm, thereby reducing holdout and bargaining costs. ${ }^{155}$

Though the vast majority of outstanding leveraged loans appears to be cov-lite, then, split control rights created at the deal level complexify the situation somewhat. That very few leveraged loan contracts specify maintenance covenants does not imply that covenant constraints are absent. Regulators and rating agencies may therefore be too quick to characterize cov-lite loans as simply profligate lending. Instead, they may be overestimating the risks in the leveraged loan market.

BNY study loans from 2005-14. ${ }^{156}$ Completely cov-lite deals comprise less than $2 \%$ of their sample. ${ }^{157}$ Contrast this with the proportion of cov-lite loans in the sample. In 2005, cov-lite term loans were close to zero; by 2014, close to $40 \%$ were cov-lite. And as earlier noted, by 2018 , cov-lite loans comprised about $85 \%$ of the leveraged loan market by volume. ${ }^{158}$ At the same time, the frequency of deals with no maintenance covenant is only $1 \%$ and has not increased in recent years. ${ }^{159}$ So almost all leveraged loan borrowers are subject to financial covenants in at least one of their loans, typically the revolving line of credit.

Consistent with the specialized monitoring that split control hopes to accomplish, leveraged loan syndicates are structured to facilitate monitoring in the presence of split control rights. Compared to deals without split control,

\footnotetext{
${ }^{153}$ Berlin, Nini \& Yu, supra note 127 , at 250.

${ }^{154}$ In no case were the revolving lenders excluded from control in the BNY sample. So "split control" essentially means that a term loan was excluded from the control features provided by covenants. Id. at 255 . Term loans also include a cross-default provision, such that a default in the revolver also triggers a default in the term loan(s). Id. at 250 .

${ }^{155} \mathrm{Id}$. at 256.

${ }^{156} \mathrm{BNY}$ 's sample is limited to deals that include both a revolving line of credit and a term loan. Id. at 250 \& fig. 1 note. For that sample, $65 \%$ of deals involve a revolver and term loan with identical financial covenants. Email from Greg Nini (Jan. 29, 2021). An Online Appendix extends the sample period through the second quarter of 2018, showing about a $20 \%$ increase in the frequency of split control rights from 2014 . Berlin, Nini \& Yu, supra note 127, Online Appendix at 12-13 \& fig. OA.1; available at https://ssrn.com/abstract=3459733.

${ }^{157}$ Berlin, Nini \& Yu, supra note 127 , at 250 .

${ }^{158}$ Martin-Buck, supra note 135, at 44.

${ }^{159}$ Berlin, Nini \& Yu, supra note 127, at 255.
} 


\section{Do Lenders Still Monitor? \\ Leveraged Lending and the Search for Covenants}

the revolving loan syndicate is more concentrated (has fewer lenders), the mean lender's commitment is larger, and most importantly, the mean agent's commitment is larger, both by dollar amount and share of the total commitment, ${ }^{160}$ similar to traditional syndicated lending. ${ }^{161}$ Moreover, borrowers subject to split control rights violate covenants at the same rate as other firms, ${ }^{162}$ which suggests that split control rights do work to enforce the discipline of financial covenants.

Split control enables the covenants, monitoring, and renegotiation that are customary in traditional syndicated lending. The agent bank leads the syndicate, taking a significant stake in the loan to ensure other syndicate members against moral hazard. As earlier described, covenants act as a screening mechanism ex ante and as a trip wire ex post, causing the agent to assess the borrower's situation and either renegotiate the covenant or waive the violation. This applies even for loans held by CLOs. ${ }^{163}$ This monitoring benefits not only the banks, but also bondholders and equity holders. ${ }^{164}$

Split control helps address bargaining frictions among leveraged lenders induced by the large presence of institutional lenders. The institutional tranches of a leveraged loan deal typically involve more lenders and more diverse lenders than does a bank tranche. ${ }^{165}$ Institutional lenders also experience fewer repeat interactions with each other, so relationships among them will be less likely. Finally, a lively secondary market in institutional leveraged loans means that syndicate members will change over the life of the loan. These various features imply that institutional loans are more difficult to renegotiate. ${ }^{166}$ In BNY's sample, the incidence of split control rights is almost four times more likely among deals with an institutional tranche. ${ }^{167}$ Split control rights have emerged to reduce renegotiation costs, and are far more prevalent with institutional deals than deals without an institutional tranche. ${ }^{168}$

${ }^{160} I d$. at $258-59 \&$ tbl. 4.

${ }^{161}$ See supra notes 63-68 and accompanying text.

${ }^{162} I d$. at 250.

${ }^{163} \mathrm{Id}$. at 251.

${ }^{164}$ James, supra note 4, at 219; Nini, Smith \& Sufi, supra note 5; Datta, Datta \& Patel, supra note 4, at 437.

${ }^{165}$ In BNY's sample, the mean number of lenders in an institutional term loan (defined as a deal containing an institutional tranche) is nine times greater than for other term loans (191 versus 20). Berlin, Nini \& Yu, supra note 127 , at $261 \&$ tbl. 6 .

${ }^{166}$ Cem Demiroglu \& Christopher M. James, Bank Loans and Troubled Debt Restructurings, 118 J. FIN. ECON. 192 (2015); Matthew G. Osborn, The Cost of Easy Credit: Loan Contracting with Non-Bank Investors, Working Paper (Nov. 3, 2014), available at https://ssrn.com/abstract=2499798; ; Mehdi Beyhaghi, Ca Nguyen \& John K. Wald, Institutional Investors and Loan Dynamics: Evidence from Loan Renegotiations, 56 J. CORP. FIN. 482 (2019) (showing that nonbanks are more likely to exit a syndicate than participate in renegotiation).

${ }^{167}$ Berlin, Nini \& Yu, supra note 127, at 251. BNY also rule out alternative explanations for the rise of split control rights. $I d$.

${ }^{168} I d$. at 258-61 \& fig. $3 \&$ tbl. 5. BNY note that during the financial crisis, the average fee for a covenant modification following a violation was $80 \%$ higher for institutional loans than for noninstitutional loans, before the widespread use of split control rights. Id. at 262-23 \& tbl. 7. In an Online Appendix, BNY extend their sample though the second quarter of 2018, showing that the frequency of split control rights has increased significantly. Online App. at 13-14 \& fig. OA.1 \& tbl. OA.4. 


\section{Do Lenders Still Monitor? \\ Leveraged Lending and the Search for Covenants}

The advent of split control rights should cause some rethinking of the traditional assumptions surrounding leveraged and cov-lite loans. ${ }^{169}$ Once individual loans are matched with the deals that spawned them, lender governance seems again to be pervasive. Moreover, failing to account for split control may lead to bias or erroneous conclusions. For example, analyses attempting to explain cov-lite loan spreads or covenant tightness may miss the mark if only loan-level-but not deal-level-covenant structure is considered.

\section{B. Earnings Add-backs and Informativeness}

In addition to growth in leveraged and cov-lite loans, earnings addbacks have caused concern with regulators. ${ }^{170}$ Add-backs may exacerbate the trend toward higher leverage, given EBITDA's key role in leverage measures for financial covenants. ${ }^{171}$ Private debt contracts often include bespoke accounting provisions that allow for adjustments to financial performance covenant earnings. According to one study, such adjustments to FASBGAAP-based net income and FASB-GAAP-based EBITDA increase income by economically large amounts. Performance covenant earnings exceed FASB-GAAP net income for more than $99 \%$ of loan contracts, and exceed FASB-GAAP EBITDA for more than $84 \%$ of contracts. Magnitudes are also large: for the median firm, FASB-GAAP net income is about $87 \%$ lower than performance covenant earnings, and FASB-GAAP EBITDA is lower by about $10 \% .{ }^{172}$

At the same time, however, it appears that permissiveness with addbacks has compensating benefits. Permissiveness improves the informativeness of EBITDA-based contract terms like financial covenants. Contractual accounting rules for performance covenant earnings are generally better at predicting future cash flows than are GAAP measures. ${ }^{173}$

Additional contractual innovations emerged to reduce renegotiation frictions as well. "Amend and Extend" provisions allow a borrower to extend the maturity of any consenting lender's slice of the syndicated loan, subject to the terms of the borrower's extension offer, including an increase in rate or fees and/or modification of the amortization schedule. This feature enables the borrower and particular lenders to tailor their loan slice to the particular circumstances they face, without having to get unanimous consent of lenders, as would be customary. A "Refinance Facility" enables a borrower to create an additional term loan tranche based on an existing credit agreement, provided that the proceeds are used to refinance part of the existing loan. This allows the borrower to refinance with a subset of lenders, typically to obtain a lower rate. Without such flexibility, the borrower would be required to make any prepayments on a pro rata basis to all existing lenders. Berlin, Nini \& Yu, supra note 127, at 263 \& Online App. 10-11.

${ }^{169} \mathrm{Cf}$. Bratton, supra note 138, at 479 (noting that junior tranches of leveraged loans sold to institutional lenders have longer maturities and higher yields and are publicly traded; concluding that public trading "reinforces resistance to covenants," and that cov-lite terms drive a convergence between the leveraged loan and high yield bond markets).

${ }^{170}$ BDDH's sample is not clearly comprised only of leveraged loans, but mean spread of their sample is 170 bps; BDDH, supra note 150, at 26-27 n.22; which suggests that many observations would be considered leveraged loans.

${ }^{171}$ Inflated EBITDA in the numerator of a financial ratio overstates the borrower's ability to cover upcoming payment obligations, like fixed charges or interest payments. When inflated EBITDA is in the denominator, the ratio understates borrower leverage.

${ }^{172}$ Scott D. Dyreng, Rahul Vashishtha \& Joseph Weber, Direct Evidence on the Informational Properties of Earnings in Loan Contracts, 55 J. ACCOUNT RES. 371, 373 (2017).

${ }^{173} I d$. at 374 . 


\section{Do Lenders Still Monitor? \\ Leveraged Lending and the Search for Covenants}

$[\mathrm{N}]$ onrecurring items are often excluded from adjusted EBITDA when the firm has previously incurred nonrecurring items, but they are included when they are informative of future performance.... [S]tudies suggest that FASB GAAP does not sufficiently fulfill the informational needs of debt contracting parties and the shortcomings are addressed through contractual tailoring. ${ }^{174}$

Badawi, Dyreng, de Fontenay, and Hills (BDDH) create a permissiveness index to track seven different categories of add-backs used in private loan agreements to augment EBITDA. ${ }^{175}$ "Permissiveness" in this context refers not to the magnitudes of EBITDA adjustments, but to the adjustment categories below:

- Non-cash charges

- Cash charges for extraordinary or non-recurring items

- Cash charges for restructuring

- Projected cash savings from synergies, restructurings, etc.

- Fees and expense related to acquisitions, investments, equity or debt issuances, etc.

- Management/advisory fees payable to sponsor

- Miscellaneous additional addbacks

Use of an adjustment category increases a loan's permissiveness score by 1 . Summing up adjustment categories for a loan generates a score between 1 and 8 for that loan, ${ }^{176}$ with 1 being the least permissive (no add-back category used) and 8 being the most permissive (all seven add-back categories used). Mean permissiveness (standard deviation) from their sample is 3.61 (1.74). ${ }^{177}$ $\mathrm{BDDH}$ find that permissiveness increases with deal size, maturity, leverage, and collateral, suggesting more permissive definitions of EBITDA with larger and riskier loans. ${ }^{178} \mathrm{BDDH}$ suggest that greater permissiveness begets better informativeness to lenders by allowing the borrower to exclude noisy information not reflective of the borrower's earnings potential or ability to honor future payment obligations. Add-backs for extraordinary or nonrecurring items, for example, may offer a clearer picture of the borrower's future earnings than leaving those extraordinary charges unaddressed. ${ }^{179}$

\footnotetext{
${ }^{174} \mathrm{Id}$. at 376 . It also appears that conservative accounting for earnings, once thought to be useful for lenders in mitigating downside risk, induces too many false positive violations, which fail to predict future distress and instead trigger costly renegotiations and inefficient wealth transfers. Id. at 372 .

${ }^{175} \mathrm{BDDH}$, supra note 150 .

${ }^{176} I d$. at 57 , Appendix C.

${ }^{177} I d$. at 2.

${ }^{178}$ Badawi, et al., supra note 150 , at 19-21 \& 45 tbl. 5.

${ }^{179}$ The most common EBITDA adjustments remove transitory earnings items, affecting about one-fifth of contracts. Ninzhong Li, Negotiated Measurement Rules in Debt Contracts, 48 J. ACCOUNT. RES. 1103 (2010); Peter R. Demerjian, Accounting Standards and Debt Covenants: Has the "Balance Sheet Approach" Led to a Decline in the Use of Balance Sheet Covenants?, 52 J. ACCOUNT. ECON. 178 (2011); Anne Beatty, Lin Cheng \& Tzachi Zach, Nonrecurring Items in Debt Contracts, 36 CONTEMP. ACCOUNT. RES. 139 (2019).
} 


\section{Do Lenders Still Monitor? \\ Leveraged Lending and the Search for Covenants}

Also, rather than assuming standardized financial covenants, BDDH use a mix of machine learning techniques and hand collection to create a dataset that captures actual covenant thresholds and realized covenant violations. They show that relying on standardized covenant measures risks overestimating realized violations, and that the likelihood of overestimating a violation increases with the level of permissiveness. ${ }^{180}$

BDDH show a number of interesting results. Contractual EBITDA is more permissive with accrual volatility, consistent with findings that accruals may not otherwise usefully translate into informativeness for lenders with respect to borrowers' financial condition. ${ }^{181}$ Conversely, cash flow volatility is negatively associated with permissiveness, suggesting that cash flow volatility reflects useful information about the borrower's ability to honor it payment obligations.

Permissiveness is also increasing in the ex ante costs of renegotiation. Covenant violations may be costly to the parties, so they have incentive to contract in a way that triggers a violation only when the borrower's performance signals actual deterioration. Especially when renegotiation costs are high, as with institutional leveraged loan tranches, reducing the incidence of false positive violations is key. ${ }^{182}$

Consistent with the improved informativeness that high permissiveness brings, the market response to a covenant violation with high permissiveness is more severe than with low permissiveness, since the violation is less likely to be a false positive and more likely to reflect the borrower's true distress. The equity market reaction to a covenant violation is therefore more negative when permissiveness is high. ${ }^{183}$ Moreover, permissiveness is negatively related to both covenant slack and covenant violations. That is, covenants are tighter and false positive violations are fewer. ${ }^{184}$ This suggests that permissiveness improves the signal to lenders concerning the borrower's true condition by removing less informative features of accounting earnings from the EBITDA definition contracted for in the loan agreement. Finally, credit spreads also increase with permissiveness, suggesting that lenders may charge for the risk of false negatives. ${ }^{185}$

${ }^{180} \mathrm{BDDH}$, supra note 150 , at 28-30 \& 50 tbl. 9.

${ }^{181}$ Patricia M. Dechow \& Ilia D. Dichev, The Quality of Accruals and Earnings: The Role of Accrual Estimation Errors, 77 ACCT'G REV. 35 (2002).

${ }^{182}$ BDDH, supra note 150, at 27-28 \& 38 fig. 2.

${ }^{183}$ Id. at $23-25$ \& 48 tbl. 7.

${ }^{184} \mathrm{Id}$. at 4.

${ }^{185} \mathrm{Id}$. at $25-27 \& 49$ tbl. 8 . One potential caveat is that indices are often tricky to interpret. Capturing the specific mechanisms that drive empirical results based on indices is sometimes a fraught endeavor. With the BDDH permissiveness index, for example, equal weighting may be a convenient default position, but it offers a somewhat blunt metric to capture the interesting results they find. Magnitudes of add-backs within specific categories, or other prospective mechanisms, for instance, may help capture additional nuance.

Almost two decades into the debates over dueling corporate governance indices, for example, scholarly consensus on what matters for corporate governance remains elusive. Gompers, Ishii, and Metrick (GIM) proposed the first widely debated governance index - the G-index-which relies on twenty-four equally weighted governance features, attempting to measure governance quality and the degree of managerial entrenchment. GIM found a significant inverse correlation between management entrenchment and firm value and performance, using Tobin's Q, stock returns, and operating performance as their dependent variables. Paul A. Gompers, Joy L. Ishii \& Andrew Metrick, Corporate Governance and Equity Prices, 118 


\section{Do Lenders Still Monitor? \\ Leveraged Lending and the Search for Covenants}

\section{The Turn Toward Efficient Covenants}

At first blush, weaker covenants may seem like a bad idea. They may encourage moral hazard, leaving borrowers too free to take ill-advised risks and blunting lenders' ability or incentive to monitor. Strict covenants, on the other hand, offer responsive tripwires to alert the lender when the borrower's performance deteriorates or it strays toward a risky path. Regular feedback in this regard may enable both lender and borrower to gain new information about each other and set expectations about the future of the borrower's business. This information acquisition and expectation setting will be especially useful for new lending relationships. ${ }^{186}$

At the same time, however, strict covenants come with costs. They constrain the borrower's latitude to run its business ex ante, ${ }^{187}$ and they require more regular lender intervention ex post, since violations become more frequent. ${ }^{188}$ Granted, waiver is the most common response, but even that requires action on the lender's part. Generally, the lender must investigate, decide on the severity of the violation, negotiate with the borrower, and then document the resolution. Over the life of a loan, the task of managing violations of varying severity may not be worth the candle. Ultimately, the lender simply seeks to guard against the prospect of the borrower's payment default. Parties to loan agreements may pursue optimal covenants to minimize these costs.

Over the last few decades, covenants have evolved. Balance sheet covenants have become more scarce relative to cash flow covenants in private

Q.J. ECON. 107, 144 (2003) (finding a relationship between an index of corporate governance measures and stock performance during the 1990s). Bebchuk, Cohen, and Ferrell (BCF) criticized GIM's findings, asserting instead that only six of GIM's twenty-four governance features mattered. Those six features make up BCF's E-index; for them, the other features are just noise. Lucian Bebchuk, Alma Cohen, \& Allen Ferrell, What Matters in Corporate Governance?, 22 REV. FIN. STUD. 738 (2008). Other governance indices and criticism of the G-index and the E-index followed. John E. Core, Wayne R. Guay \& Tjomme O. Rusticus, Does Weak Governance Cause Weak Stock Returns?: An Examination of Firm Operating Performance and Investor Expectations, 61 J. FIN. 655, 685 (2006) (challenging GIM's findings on stock returns); Sanjai Bhagat \& Brian Bolton, Corporate Governance and Firm Performance, 14 J. CORP. FIN. 257 (2008) (finding no correlation between governance measures and stock returns for either the G-index or E-index); Miroslava Straska \& H. Gregory Waller, Antitakeover Provisions and Shareholder Wealth: A Survey of the Literature, 49 J. FIN. QUANT. ANALYS. 933 (2014) (arguing that the eighteen measures BCF would drop from the Gindex predict takeover likelihood); Jonathan M. Karpoff, Robert J. Schonlau \& Eric W. Wehrly, Do Takeover Defense Indices Measure Takeover Deterrence?, 30 REV. FIN. STUD. 2359 (2017) (proposing an index using instrumented versions of the G-index and E-index that predict takeover likelihood).

${ }^{186}$ Nicolae Garleanu \& Jeffrey Zwiebel, Design and Renegotiation of Debt Covenants, 22 REV. FIN. STUD. 749 (2009). The new lender may later relax covenants as the borrowing relationship generates new information about the borrower. Id.; Wouter Dessein, Information and Control in Ventures and Alliances, 60 J. FIN. 2513 (2005).

${ }^{187}$ Smith \& Warner, supra note 1, at 123-24.

${ }^{188}$ Mitchell Berlin \& Loretta J. Mester, Debt Covenants and Renegotiation, 2 J. FIN. INTERMEDIATION 95 (1992); Garleanu \& Zwiebel, supra note 186; Valeri V. Nikolaev, Scope for Renegotiation in Private Debt Contracts, 65 J. ACCOUNT. \& ECON. 270, 274 (noting the tradeoff with renegotiation, which enables monitoring of the borrower, but also allows the lender to interfere with management decisions and hold up the firm's investments). 


\section{Do Lenders Still Monitor? \\ Leveraged Lending and the Search for Covenants}

debt contracts. ${ }^{189}$ Peter Demerjian hypothesizes that changes in accounting standard setting have contributed to making the balance sheet less useful for loan contracting. ${ }^{190}$ Standard setting shifted focus from the determination of net income to the valuation of assets and liabilities (the balance sheet approach), and new accounting standards emerged. With this balance sheet approach came balance sheet adjustments, which embrace estimates of asset and liability values, as well as discretion in the timing of recognition of changes in value, among other things. These adjustments may limit the utility of balance sheets for debt contracting parties, who rely on conservative balance sheets and high verifiability in determining the lower bound of a firm's liquidation value. Not all adjustments can be verifiably measured. ${ }^{191}$ Error or bias may result. ${ }^{192}$

The turn away from balance sheet covenants has been auspicious. Cash flow covenants turn out to be more efficient than balance sheet covenants. Cash flow covenants trigger false positives - where the borrower violates but only a low likelihood of distress exists - far less often than balance sheet covenants. Griffin, Nini, and Smith (GNS) confirm the trend toward cash flow covenants and away from balance sheet covenants that Demerjian identifies, as well as showing the relative efficiency of cash flow covenants. ${ }^{193}$ Over GNS's twenty-year sample period, the use of balance sheet covenants has given way to cash flow covenants, as Figure 2 shows. By 2016, cash flow covenants predominated.

${ }^{189}$ Demerjian, supra note 179. In 1996, more than $80 \%$ of deals included balance sheet covenants. By 2007 , balance sheet covenant usage had dropped to $32 \%$. Cash flow covenants showed no similar declining trend. Id.

${ }^{190}$ Demerjian is careful not to overclaim. There may be other factors that also affect the observed changes in covenant use. Id. at 196.

${ }^{191}$ For example, new standards include wider use of fair value accounting. But one form of fair value accounting allows for unobservable inputs into the valuation. $I d$. at 182.

${ }^{192}$ In addition, researchers have offered evidence that managers use discretion opportunistically across a number of accounting contexts. Jennifer Francis, J. Douglas Hanna \& Linda Vincent, Causes and Effects of Discretionary Asset Write-Offs, 34 J. ACCOUNT. RES. 117 (1996); Edward J. Riedl, An Examination of LongLived Asset Impairments, 79 ACCOUnT. REV. 823 (2004); Anne Beatty \& Joseph Weber, Accounting Discretion in Fair Value Estimates: An Examination of SFAS 142 Goodwill Impairments, 44 J. ACCOUNT RES. 257 (2006); Karthik Ramanna \& Ross L. Watts, Evidence on the Use of Unverifiable Estimates in Required Goodwill Impairment, 17 ReV. AcCounT. StuD. 749 (2012); Patricia M. Dechow, Linda A. Myers \& Catherine Shakespeare, Fair Value Accounting and Gains from Asset Securitizations: A Convenient Earnings Management Tool with Compensation Side-Benefits, 49 J. ACCOUNT. \& ECON. 2 (2010).

${ }^{193}$ Thomas P. Griffin, Greg Nini \& David C. Smith, Losing Control?: The 20-Year Decline in Loan Covenant Restrictions 3, Working Paper (Dec. 2019), available at https://ssrn.com/abstract=3277570. 


\section{Figure 2: BALANCE SHEET AND CASH Flow FinANCIAL COVENANTS 194}

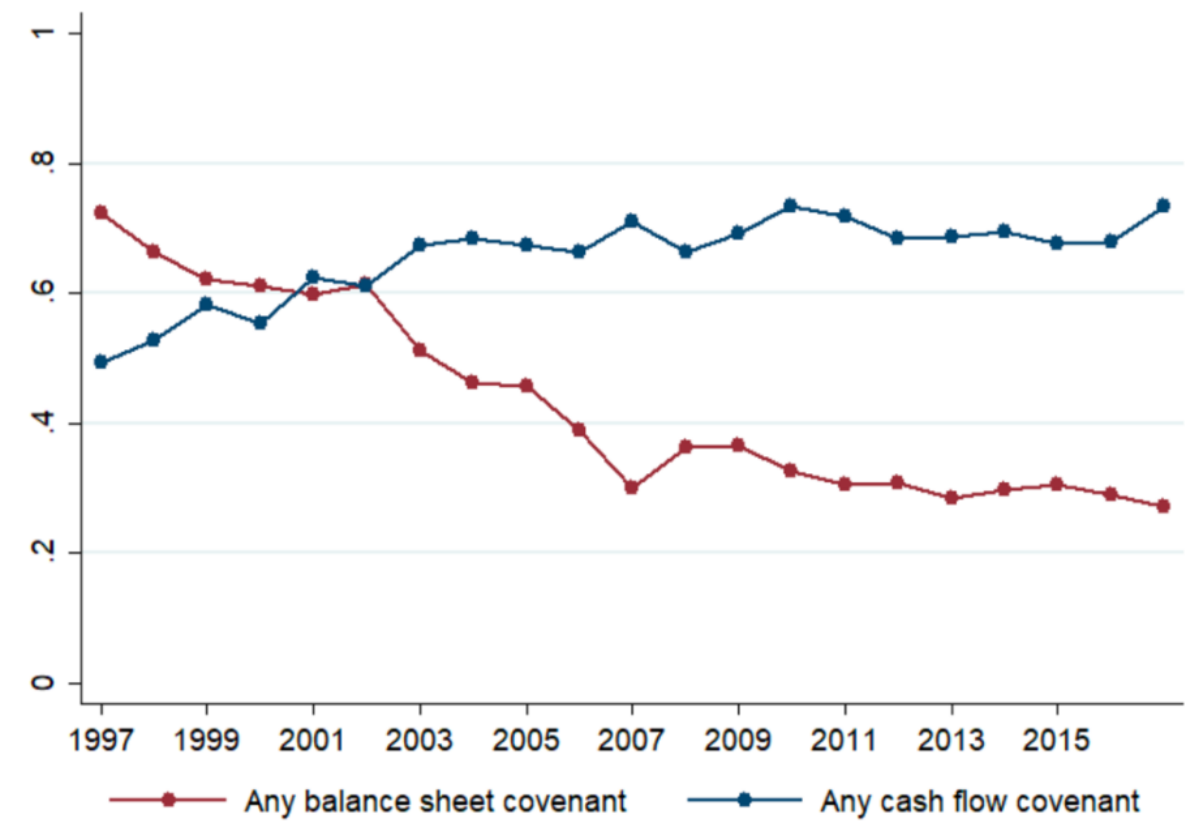

The figure plots the annual mean fraction of loans that contain a financial covenant based on a balance sheet item (red) and based on a cash flow item (blue). We classify covenants as cash flow if they are written on EBITDA and balance sheet otherwise. The groups are not mutually exclusive because loan packages often contain more than one covenant.

Financial covenants have also become less restrictive, as captured in Figure 3. The number of financial covenants for a given loan has decreased roughly by half in the two decades from 1997 to 2017. The remaining covenants are more than twice as slack as covenants two decades prior in terms of distance to the covenant threshold at origination. Even revolver-only leveraged loan packages show less restrictive covenants. ${ }^{195}$ Reported violations are correspondingly fewer: the annual proportion of public firms reporting a loan covenant violation dropped by nearly $70 \% .{ }^{196}$

\footnotetext{
${ }^{194}$ Griffin, Nini \& Smith, supra note 193, at 42 fig. 4.

${ }^{195} \mathrm{Id}$. at 30 .

${ }^{196} I d$. at $1 \& 40$ fig. 2.
} 


\section{Figure 3: FinANCIAL COVENANTS IN CORPORATE LOAN AgREEMENTS 197}

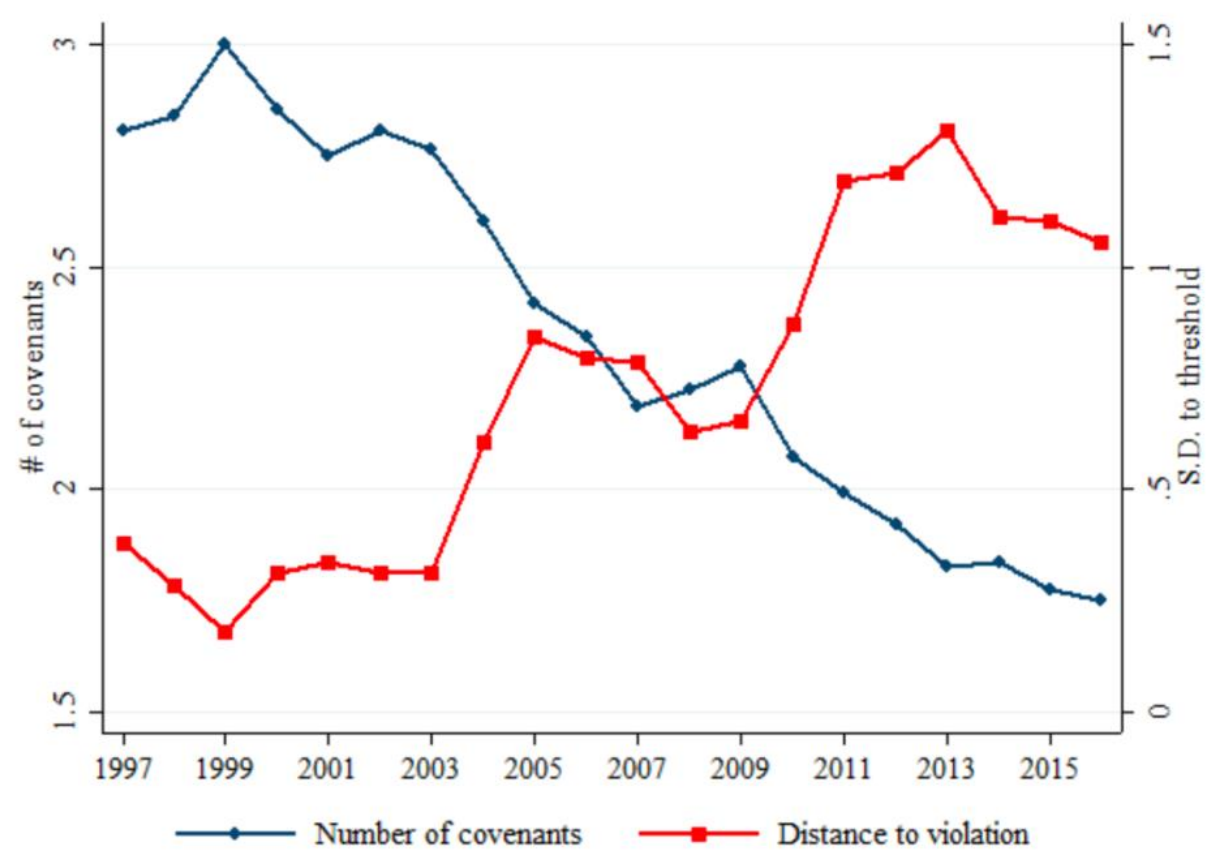

The figure plots the annual mean number of covenants (blue line, measured on left axis) and the annual mean number of standard deviations to violation for the tightest covenant (red line, measured on right axis) at contract origination. The sample is a large set of loans in Dealscan issued to U.S. nonfinancial firms in Compustat.

This shift to less restrictive covenants is driven by removal of the less informative balance sheet covenants, relying instead on the more efficient cash flow covenants. GNS show a secular decline in false positives, without a large increase in false negatives. ${ }^{198}$ So although the overall use of covenants has declined, covenants seem to be more discriminating in differentiating distress from non-distress situations. Violations that result only in a waiver (referred to as "foot faults") are also far more prevalent in the early part of the sample period. In 1997, foot faults account for almost two-thirds of new covenant violations. By 2016, foot faults are closer to one-third of new violations. Overall, balance sheet covenants were also $40 \%$ more likely to result in foot faults than cash flow covenants. ${ }^{199}$

The trends toward lower ex ante covenant strictness and fewer ex post violations seem to be driven by lenders' evolution to covenant structures with higher "signal-to-noise" ratios. The optimal covenant threshold will be tighter as the probability of distress increases, and looser in the relative costs of false

${ }^{197}$ Griffin, Nini \& Smith, supra note 193, at 39 fig. 1.

${ }^{198}$ A false negative in this context arises when a borrower becomes distressed without having triggered a covenant violation.

${ }^{199} \mathrm{Id}$. at 4. 


\section{Do Lenders Still Monitor? \\ Leveraged Lending and the Search for Covenants}

positives to false negatives. ${ }^{200}$ In this way, financial covenants can better differentiate healthy from distressed borrowers.

These trends do not appear to be driven by changes in renegotiation costs related to changes in the number or type of corporate lenders (i.e., bank versus non-bank institutional lenders) or the growth of cov-lite loans. GNS uncover no evidence that the presence of leveraged loans, loans marketed to institutional investors, private equity deals, improved credit quality, or increased credit supply explain the results. ${ }^{201}$

\section{CONCLUSION}

In this Article, I have explained the rise of the leverage loan market and regulators' concerns about excessive risk in that market. Eight-five percent of leveraged loans are covenant-lite: they contain no financial maintenance covenants. Reported covenant violations have dropped. This seeming dearth of guardrails in a risky market implicates both systemic risk and corporate governance concerns. The new lender governance described above, however, offers interesting new avenues for addressing both systemic risk concerns and governance. Lenders seem to have innovated in three important ways to curb risk and facilitate renegotiation by resort to private ordering in loan agreements.

With split control rights, the informativeness of EBITDA add-backs, and the general turn to efficient covenants, it appears that borrowers and lenders have created innovative covenant structures to address their own private interests, as well as regulators' fears of unsound lending practices. In deals that include split control rights, bank lenders - and only the bank lenders - enjoy discretion to apply, renegotiate, or waive traditional financial maintenance covenant constraints with respect to all loans that are part of the deal. Placing this discretion with the bank lenders reduces holdout problems and facilitates renegotiation. The advent of split control strongly suggests that traditional financial covenants will continue to matter in the leveraged loan market. Leveraged and cov-lite loans will not be bereft of financial covenant constraints. Instead, traditional covenants from bank revolving credit agreements will cabin risk taking. Covenant coverage will not disappear. In this respect, the new governance closely replicates the function of the old governance. Given the new learning on split control rights, merely tallying the number of cov-lite loans and the volume of cov-lite loan dollars would seem to tell regulators and rating agencies little about systemic risk. Instead, analysts need to discern covenant structures from the deal perspective in order to appreciate borrower firms' overall covenant constraints.

That said, the loans at issue are still below-investment grade, many sporting under-reported leverage ratios based on deal-related add-backs. ${ }^{202}$

\footnotetext{
${ }^{200} I d$. at 2.

${ }^{201} I d$. at 4-5, 31. More generally, the secular trend that GNS identify does not focus solely on the leveraged loan market.

${ }^{202}$ See supra notes 142-144 and accompanying text.
} 


\section{Do Lenders Still Monitor?

So while the fear of flying may be assuaged somewhat, it will likely not soon dissipate. At the same time, add-backs do not necessarily represent unmitigated profligacy. Though the leveraged loan market offers real risks of excessive leverage, more permissiveness with add-backs appears to improve informativeness, generating better predictions of future cash flows related to financial covenants. Bespoke contractual accounting rules for financial covenant earnings predict future cash flows more reliably than GAAP measures. One result is tighter covenants with fewer false positive violations. More generally, with the secular trend toward looser and more efficient covenants, based on cash flow covenants instead of balance sheet covenants, covenants have become more efficient. Covenants with higher signal to noise benefit lenders and borrowers alike, hitting a tripwire only when the firm is near distress, and reducing costs overall.

Together these evolving trends suggest that private innovations in lending arrangements may reduce risk in leveraged lending markets, facilitate lower-cost renegotiation, and improve lender governance. Regulators' worries about excessive risk in the leveraged loan market may be overblown insofar as they overlook the sophisticated loan structures emerging to address lender governance concerns and to avoid renegotiation frictions. 